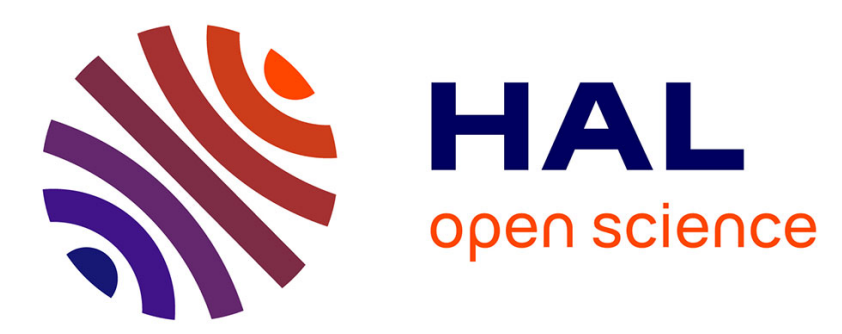

\title{
Natural Products and Chemical Biology Tools: Alternatives to Target Epigenetic Mechanisms in Cancers
}

Santiago Lascano, Marie Lopez, Paola B Arimondo

\section{- To cite this version:}

Santiago Lascano, Marie Lopez, Paola B Arimondo. Natural Products and Chemical Biology Tools: Alternatives to Target Epigenetic Mechanisms in Cancers. Chemical Record, 2018, 18 (12), pp.18541876. 10.1002/tcr.201800133 . hal-03082748

\section{HAL Id: hal-03082748 https://hal.science/hal-03082748}

Submitted on 18 Dec 2020

HAL is a multi-disciplinary open access archive for the deposit and dissemination of scientific research documents, whether they are published or not. The documents may come from teaching and research institutions in France or abroad, or from public or private research centers.
L'archive ouverte pluridisciplinaire HAL, est destinée au dépôt et à la diffusion de documents scientifiques de niveau recherche, publiés ou non, émanant des établissements d'enseignement et de recherche français ou étrangers, des laboratoires publics ou privés. 


\title{
Natural products and chemical biology tools: alternatives to target epigenetic mechanisms in cancers
}

Santiago Lascano, ${ }^{1}$ Marie Lopez ${ }^{1 *}$ and Paola B. Arimondo ${ }^{2 *}$

${ }^{1}$ Institut des Biomolécules Max Mousseron (IBMM), UMR 5247 CNRS-Université de MontpellierENSCM, 240 avenue du Prof. E. Jeanbrau, 34296 Montpellier cedex 5, France

${ }^{2}$ Epigenetic Chemical Biology, Institut Pasteur, CNRS UMR3523, 28 rue du Docteur Roux, 75724 Paris cedex 15, France

*co-corresponding authors:

emails: marie.lopez@cnrs.fr; paola.arimondo@pasteur.fr

\begin{abstract}
DNA methylation and histone acetylation are widely studied epigenetic modifications. They are involved in numerous pathologies such as cancer, neurological disease, inflammation, obesity, etc. Since the discovery of the epigenome, numerous compounds have been developed to reverse DNA methylation and histone acetylation aberrant profile in diseases. Among them several were inspired by Nature and have a great interest as therapeutic molecules. In the quest of finding new ways to target epigenetic mechanisms, the use of chemical tools is a powerful strategy to better understand epigenetic mechanisms in biological systems. In this review we will present natural products reported as DNMT or HDAC inhibitors for anticancer treatments. We will then discuss the use of chemical tools that have been used in order to explore the epigenome.
\end{abstract}

\section{1/ Introduction}

Epigenetic modifications, including DNA methylation and histone acetylation, have attracted plenty of attention for several years in the field of anticancer therapies. These modifications are deregulated in cancer leading to silencing of tumour suppressor genes and therefore participating to tumour formation and proliferation ${ }^{[1,2]}$ Efforts have been put into the discovery of inhibitors of DNA methyltransferase (DNMT) and histone deacetylase (HDAC), the enzymes responsible for these modifications. Although four HDAC inhibitors (HDACi) are today approved by the FDA (vorinostat, panabinostat, belinostat, 
romidepsin) and one by the Chinese CFDA (chidamide), the discovery of isoform-selective inhibitors is necessary in order to target more efficiently and selectively the HDACs. Regarding DNMT inhibitors (DNMTi), two compounds are FDA approved for treatment of leukaemia, 5-azacytidine (5azaC) and 5-aza-2-deoxycytidine $(5 \mathrm{azadC}) .{ }^{[3,4]}$ They are both nucleoside analogues that need to incorporate into DNA/RNA to be active. This incorporation is neither site- nor cell-specific, which can lead to important secondary effects. Additionally, their instability limits their use. Research efforts aimed at identifying non-nucleoside DNMTi, ${ }^{[5]}$ but to date none of them has showed enough potency to be considered as drug candidate.

In this context, natural products constitute a vital source to find novel chemical scaffolds as HDACi or DNMTi. Because living beings are constantly battling for survival, often against living being of different species or even different life kingdoms altogether, it is hypothesized that there is an evolutionary pressure for the generation of secondary metabolites that can act as antibiotics, antifungals, phytoalexins, etc., ${ }^{[6]}$ or have no evident utility altogether. ${ }^{[7]}$ Because of this demanding task, Nature produces an overwhelming number of structures, with beautiful complexity and diversity, which interact with a variety of enzymes and proteins in different types of organisms. Researchers have successfully taken advantage of the chemical scaffolds optimized by Nature to design new drugs. ${ }^{[8,9]}$ One of the main challenges of the use of natural products is the identification of "hits", as natural products are most of the time found in complex mixtures and in minute amounts. However new techniques for high-throughput screening are continuously being reported and there is good hope that they will allow facilitate drug discovery.

Additionally, the use of chemical tools scanning the epigenetic space directly in the relevant biological system can constitute a powerful strategy. These chemical biology strategies can be highly valuable to either better understand the mode of action of natural products in cells or to identify new epigenetic pathways specific of a pathological context and lead to the discovery of new epi-targets.

In this review, we will first report the natural products that were identified as HDACi and DNMTi and more briefly for other epi-targets. We restricted the scope of this review to isolated single compounds that could be used as new drug or new hit for drug discovery without considering natural extracts. 
Then we will describe how chemical tools were used in Epigenetics to explore the epi-drug mechanism of action and to identify new therapeutic targets.

\section{2/ Histone deacetylase-modulating natural products}

HDACs are divided in four different classes. Class I, II and IV are zinc-dependent enzymes with a highly conserved deacetylase domain and major residues differences at the entry of the active site. ${ }^{[10]}$ Class I HDACs are comprised of nuclear enzymes HDAC1-3 and more distantly related HDAC8, and possess an additional internal cavity, which is believed to be used for water entry and acetic acid removal after the deacetylation reaction. ${ }^{[10]}$ Class II HDACs are able to shuttle in and out of the nucleus and comprises HDAC4-7, 9 and 10, while HDAC 11 is the sole member of class IV. Class III consists in seven $\mathrm{NAD}^{+}$-dependent enzymes, called sirtuins (SIRT1-7).

The ubiquity of HDACs and their crucial role in physiological processes and the large diversity of their substrates ${ }^{[11]}$ - in addition to histones - lead therefore pan-inhibitors of HDACs to often show numerous undesirable side effects ${ }^{[12]}$ making isoform selectivity a highly desirable property.

\subsection{For HDAC inhibition (Class I and II)}

The discovery, in the late $1970 \mathrm{~s},{ }^{[13,14]}$ of the effect of sodium butyrate on histone acetylation is among the first evidence ${ }^{[15]}$ pointing towards the involvement of small molecules of natural origin in the modulation of the acetylation of histones. Sodium butyrate was later shown to be a non-competitive inhibitor of HDAC ${ }^{[16]}$ and was followed by Trichostatin A in $1990,{ }^{[17]}$ Trapoxin in $1993,{ }^{[18]}$ and many others in the following years. Trapoxin, additionally, played a central role in the understanding of HDAC enzymes, as the irreversible nature of its binding to HDAC was used to design an affinity tag for the first isolation of a mammalian HDAC enzyme. ${ }^{[19,20]}$

The large variety of natural products inhibiting HDACs can be roughly classified into different structural families and whether they bind the $\mathrm{Zn}$ atom found in the HDAC cavity or not.

\section{Zinc-binding inhibitors}

\section{General structure}

HDACi with a zinc-binding mode of action follow an almost ubiquitous structure, summarized graphically in Fig. 1. The main feature is the zinc-binding group (or ZBG), which can be a mono- or 
bi-dentate ligand, binding the metal atom in a reversible or irreversible manner. Among the known ZBG are hydroxamic acids - found in the archetypal HDACi suberoylanilide hydroxamic acid (SAHA, vorinostat, Fig. 1) - thiols, epoxyketones, $\alpha$-hydroxyketones, carboxylic acids, etc.. Because this pharmacophore mimics the substrate of HDAC enzymes, ${ }^{[21]}$ namely acetyllysines, the ZBG is followed by a hydrocarbon linker, reminiscent of the aliphatic side-chain of lysine, fitting the internal channel found in HDAC composing the catalytic pocket, and topped by a cap. This cap can be simple, such as the aromatic ring of SAHA, or more complex surface-binding groups (vide infra). Because HDAC isoforms show significant differences in the surface grooves neighbouring the catalytic pocket, surface-binding groups are often used to achieve isoform selectivity. However, other interesting results demonstrating the influence of the linker, ${ }^{[22,23]}$ ) the $\mathrm{ZBG}^{[24]}$ and other new features in the pharmacophore ${ }^{[12]}$ might be leading towards a paradigm shift. ${ }^{[25]}$

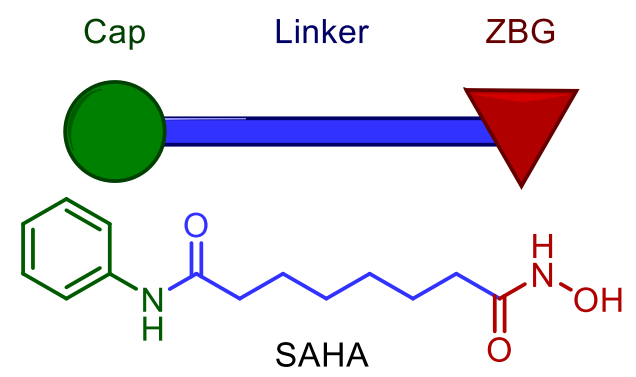

Figure 1. Common pharmacophore for zinc-binding HDACi.

\section{Cyclic depsipeptides with hidden thiol (Fig. 2)}

The reported cyclic depsipetides have complex cap group allowing for a more extensive recognition of the external parts of HDACs and thus a potentially better discrimination between isoforms. All are "prodrugs", where the active thiol is "hidden", either as disulfides that get reduced in the cell (usually by glutathione) or as a thioester in the case of largazole that gets hydrolysed.

\section{Romidepsin}

Romidepsin was isolated, under the name of FR901228, from Chromobacterium violaceum in 1994 by a team from Fujisawa Pharmaceutical Company ${ }^{[26]}$ for its antitumor activity. Sometimes simply referred to as depsipeptide or FK228, romidepsin is one of the four HDACi, and the only one from natural sources, approved by the FDA for treatment of cutaneous ${ }^{[27]}$ and peripheral T-cell 
lymphoma. ${ }^{[28]}$ At the time of the publication of this review, it is in clinical trials, alone or in combination with other drugs, in 15 other cases. (Table 1)

Table 1. Clinical trials involving romidepsin for cancer treatment

\begin{tabular}{|c|c|c|c|}
\hline Treated disease & In combination with & Trial phase & $\begin{array}{c}\text { Clinicaltrials.gov } \\
\text { ID }\end{array}$ \\
\hline Relapsed or refractory T-cell lymphoma & Duvelisib & I & NCT02783625 \\
\hline T-cell non-Hodgkin lymphoma & $\begin{array}{l}\text { Chemotherapy, stem cell } \\
\text { transplant }\end{array}$ & II & NCT01908777 \\
\hline $\begin{array}{l}\text { Locally recurrent or metastatic triple } \\
\text { negative breast cancer }\end{array}$ & Cisplatin, Nivolumab & $\mathrm{I} / \mathrm{II}$ & NCT02393794 \\
\hline $\begin{array}{l}\text { Lymphoma, chronic lymphocytic } \\
\text { leukemia, or solid tumors with liver } \\
\text { dysfunction }\end{array}$ & - & I & NCT01638533 \\
\hline $\begin{array}{l}\text { Previously untreated peripheral T-cell } \\
\text { lymphoma }\end{array}$ & Lenalidomide & II & NCT02232516 \\
\hline $\begin{array}{l}\text { Relapsed or refractory aggressive } \\
\text { lymphoma }\end{array}$ & $\begin{array}{l}\text { Gemcitabine hydrochloride, } \\
\text { oxaliplatin, dexamethasone }\end{array}$ & I & NCT02181218 \\
\hline $\begin{array}{l}\text { Relapsed or refractory lymphoma or } \\
\text { multiple myeloma }\end{array}$ & Pralatrexate & $\mathrm{I} / \mathrm{II} \mathrm{a}$ & NCT01947140 \\
\hline $\begin{array}{l}\text { Stage IB-IVB relapsed or refractory T-cell } \\
\text { lymphomas }\end{array}$ & $\begin{array}{l}\text { Pegylated liposomal } \\
\text { doxorubicin hydrochloride }\end{array}$ & I & NCT01902225 \\
\hline $\begin{array}{l}\text { Recurrent or refractory peripheral } \mathrm{T} \text {-cell } \\
\text { lymphoma }\end{array}$ & Pembrolizumab & $\mathrm{I} / \mathrm{II}$ & NCT03278782 \\
\hline Peripheral T-cell lymphoma & $\begin{array}{l}\text { Durvalumab, pralatrexate, } \\
\text { oral azacitidine }\end{array}$ & $\mathrm{I} / \mathrm{II}$ & NCT03161223 \\
\hline $\begin{array}{l}\text { Relapsed or refractory peripheral T-cell } \\
\text { lymphoma or stage IIB-IV cutaneous T- } \\
\text { cell lymphoma }\end{array}$ & Volasertib & I & NCT02757248 \\
\hline Cutaneous T-cell lymphoma & Brentuximab vedotin & I & NCT02616965 \\
\hline $\begin{array}{l}\text { T-cell leukemia or lymphoma undergoing } \\
\text { donor stem cell transplant }\end{array}$ & - & $\mathrm{I} / \mathrm{II}$ & NCT02512497 \\
\hline $\begin{array}{l}\text { Microsatellite Stable Metastatic Colorectal } \\
\text { Cancer }\end{array}$ & Azacitidine, pembrolizumab & I & NCT02512172 \\
\hline Stage IA-IVB cutaneous T-cell lymphoma & Carfilzomib & $\mathrm{I}$ & NCT01738594 \\
\hline
\end{tabular}

Data obtained from https://www.cancer.gov/about-cancer/treatment/clinical-trials/intervention/romidepsin

\section{Spiruchostatins}

Spiruchostatins A and B were isolated in 2001 from Pseudomonas sp. by Masuoka et al., followed by spiruchostatin C in 2001 and D in $2004 .{ }^{[29]}$ Spiruchostatins A-D all show low nanomolar IC $_{50}$ values for HDAC1 and values in the hundreds for HDAC6, demonstrating high selectivity for class I HDAC. ${ }^{[29,30]}$ These values were obtained in a reducing environment (100 mM dithiothreitol) in order 
to obtain the open dithiol, as unreduced spiruchostatin A lost almost all its inhibitory potency. ${ }^{[31]}$ Crabb et al. reported in 2008 potent growth inhibition against four human cancer cell lines (MCF7 and BT474, breast; A2780, ovarian; HT29, colon), with IC $_{50}$ values ranging from 1.2 for HT29 to $6.7 \mathrm{nM}$ for BT474, while Narita et al. reported similar results on almost all of thirty-nine human cancer cell lines tested with spiruchostatin A and B in 2009, ${ }^{[30]}$ and C and D in 2013. ${ }^{[29]}$ The mean $\mathrm{GI}_{50}$ value over all the lines tested allows to give an order of potency: $\mathrm{D}(3.8 \mathrm{nM})>\mathrm{B}(5.6 \mathrm{nM})>\mathrm{A}(15 \mathrm{nM})>\mathrm{C}(28$ $\mathrm{nM}) \cdot{ }^{[29]}$

Rehman et al. studied in 2014 the activity of spiruchostatins A and B in human lymphoma U937 cells and reported that both compounds induced apoptosis in the treated cells, resulting in an increase of the population of cells in sub- $\mathrm{G}_{1}$ cell phase, as well as an increased acetylation of histones $\mathrm{H} 3$ and $\mathrm{H} 4 .^{[32]}$ The authors determined that induced apoptosis was heavily dependent on the generation of reactive oxygen species (ROS) and that the inhibitors caused an increase in the expression of caspase- 3 and 8 , which play a key role in apoptosis signalling pathways.

\section{Thailandepsins and burkholdacs}

The first members of the thailandepsin family were isolated in 2011 from bacterium Burkholderia thailandensis by Cheng et al. as thailandepsins $\mathrm{A}$ and $\mathrm{B},{ }^{[33]}$ and Biggins et al., as thailandepsins $\mathrm{A}$ and C (named burkholdac B and A respectively). ${ }^{[34]}$ Thailandepsins D-F were later discovered by Wang et al. in $2012,{ }^{[35]}$ while Klausmeyer and coworkers isolated a compound they named spiruchostatin $\mathrm{C}$ in 2011. ${ }^{[36]}$ However, considering the biological source of the latter, reason mandates to include it in the thailandepsin/burkholdac family. In this review we will use the nomenclature suggested by Narita $e t$ al., i.e. burkholdac C. ${ }^{[29]}$

Thailandepsins A-F strongly inhibit recombinant $\mathrm{HDAC1}$ with $\mathrm{IC}_{50}$ values ranging from 0.2 to $2.6 \mathrm{nM}$ (for forms C and F respectively), while being much weaker inhibitors for HDAC6 (0.67-1.92 $\mu \mathrm{M}$ ) and HDAC4 (8.67-132 $\mu \mathrm{M}) .{ }^{[35]}$ Burkholdac C showed similar trends against HDAC1, 4 and $8 .{ }^{[36]}$ Wang et al. reported that thailandepsins A and B inhibit HDAC1-3 (class I) in the low nanomolar range, the distantly related HDAC8 (class 1) being only inhibited at low micromolar levels. HDAC6 (class IIB) showed better response, but thailandepsin A and B were not as active against HDAC4, 7, 9 (class IIA). 
Additionally, the reduced dithiol form was more active compared to the non-reduced one, with a more than 10,000-fold increase for HDAC2.$^{[33]}$ Additionally, thailandepsins A-C were screened against an extensive panel of human cancer cell lines, with $\mathrm{GI}_{50}$ values at low nanomolar concentrations for over $90 \%$ of the tested lines. ${ }^{[33,37]}$

Thailandepsin A was used against ovarian cancer cells by Wilson et al. in 2012, ${ }^{[38]}$ anaplastic thyroid cancer (ATC) cells by Weinlander et al. in $2014,{ }^{[39]}$ and neuroendocrine (NE) cancer cell lines by Jang et al. in 2017. ${ }^{[40]}$ In ATC cells, treatment with the compound resulted in a clear inhibition of cell growth, accompanied by an increased acetylation of histone $\mathrm{H} 4$, and a dose-dependent increase in $P 21^{W A F 1}$ and $P 27^{K i p l}$, and a decrease of survivin and $B C L-2$ expressions. ${ }^{[39]}$ In NE cancer cells, thailandepsin A strongly inhibited the growth through the activation of the Notch pathway, without cytotoxicity to lung fibroblasts. ${ }^{[40]}$

Interestingly, the groups of Xiao and Gong have produced systems in which thailandepsin $\mathrm{A}$ is incorporated in micelles for delivery in cancer cells, showing improved targeting of tumours over the free form. ${ }^{[41-43]}$

\section{Largazole $^{[44]}$}

Isolated in 2008 from a cyanobacterium Symploca sp., in Key Largo, ${ }^{[45]}$ largazole, unlike the other members of this family, "hides" its thiol as a hydrolysable thioester. Largazole and its thiol have been tested in vitro for HDAC inhibition activity, both with HeLa nuclear extracts, ${ }^{[46,47]}$ and with recombinant ${ }^{[46,48]}$ or purified ${ }^{[47,49]} \mathrm{HDAC}$ enzymes. The $\mathrm{IC}_{50}$ values differ widely, ranging from low nanomolar to low micromolar. A general trend seems however to suggest a low nanomolar affinity for HDAC1 and lower potency for class II HDACs. Largazole also inhibited cell growth in a number of human cancer cell lines: HCT-116 (colon, $\mathrm{GI}_{50} 44 \mathrm{nM}$ ), ${ }^{[46]} \mathrm{MCF}$ (breast, $\mathrm{IC}_{50} 5 \mathrm{nM}$ ), ${ }^{[47]} \mathrm{MM} 1 . \mathrm{S}$ (multiple myeloma, $\mathrm{IC}_{50} 6.2 \mu \mathrm{M}$ ), ${ }^{[49]}$ and HCT-116, A549, HEK293, HLF (colon, lung, kidney, lung fibroblast, with $\mathrm{GI}_{50}$ of $0.08,0.32,1.36$ and $0.98 \mu \mathrm{M}$ respectively). ${ }^{[50]}$ Souto et al. observed that treatment with largazole induced the accumulation of leukaemia NB4 cells in the pre- $\mathrm{G}_{1}$ cell phase at $1 \mu \mathrm{M}$ and massive cell death at $5 \mu \mathrm{M}$, as well as increasing the acetylation level of histone $\mathrm{H} 3$ and the expression of $P 21^{W A F 1 / C I P 1}{ }^{[48]}$ 
Liu et al. reported that largazole induces cell cycle arrest at the $\mathrm{G}_{1}$ phase at low concentrations (1-3.2 $\mathrm{nM})$ and $\mathrm{G}_{2} / \mathrm{M}$ arrest at higher concentrations $(\geq 10 \mathrm{nM})$ in human colon cancer HCT116 cells in $2010{ }^{[51]}$ This was associated to increased acetylation of histone $\mathrm{H} 3$, with an increase in $P 21, P 19, P 15$ and P57 and a decrease in CDK6 and cyclin D1 levels. A more general analysis of the genes affected by largazole revealed that overrepresented functional classes include those involved in chromatin assembly, negative regulation of cell cycle, transcription (up-regulated), positive regulation of transcription, intracellular protein cascade, positive regulation of nucleic acid metabolism, RNA biosynthesis and metabolism (down-regulated). No inhibition of HDAC6 was observed, as shown by the absence of change in the tubulin acetylation status. When tested on $n u / n u$ mice, largazole was well tolerated up to the highest tested concentration $(50 \mathrm{mg} / \mathrm{kg}$ ), with good bioavailability and HDAC inhibition already at $5 \mathrm{mg} / \mathrm{kg} .{ }^{[51]}$ More recently, Wu et al. reported that treatment of lung cancer A549 cells had similar effects, with up-regulation of caspase-3 and 9, $P 21$ and $P 27$ The authors observed hyperacetylation of histone $\mathrm{H} 3$ and an enhanced recruitment of the $P 21$ promoter to acetyl H3. ${ }^{[52]}$

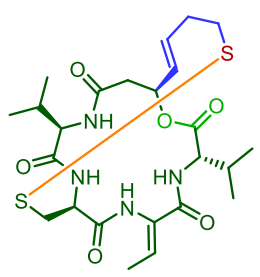

FR-901,228 FK228 Romidepsin

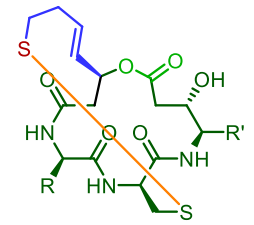

Spiruchostatin $A, R=M e, R^{\prime}={ }^{i} P$ Spiruchostatin $B, R=M e, R^{\prime}={ }^{s} B u$ Spiruchostatin $\mathrm{C}, \mathrm{R}=\mathrm{Me}, \mathrm{R}^{\prime}={ }^{\prime} \mathrm{Bu}$ Spiruchostatin $\mathrm{D}, \mathrm{R}=i \mathrm{Pr}, \mathrm{R}^{\prime}={ }^{i} \mathrm{Pr}$

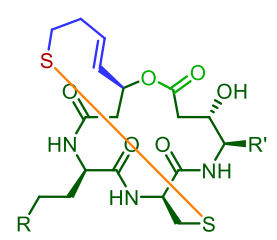

Thailandepsin A, R=SMe, $R^{\prime}={ }^{s} B u(B u r k h o l d a c ~ B)$ Thailandepsin $B, R=E t, R^{\prime}={ }^{s} B u$ Thailandepsin $\mathrm{C}, \mathrm{R}=\mathrm{SMe}, \mathrm{R}^{\prime}=\operatorname{Pr}$ (Burkholdac A) Thailandepsin $\mathrm{D}, \mathrm{R}=\mathrm{Et}, \mathrm{R}^{\prime}={ }^{\prime} \mathrm{Pr}$ Thailandepsin $\mathrm{E}, \mathrm{R}=\mathrm{SMe}, \mathrm{R}^{\prime}={ }^{i} \mathrm{Bu}$

Thailandepsin $F, R=E t, R^{\prime}={ }^{\prime} B u$ Burkholdac $\mathrm{C}, \mathrm{R}=\mathrm{SOCH}_{3}, \mathrm{R}^{\prime}={ }^{s} \mathrm{Bu}$

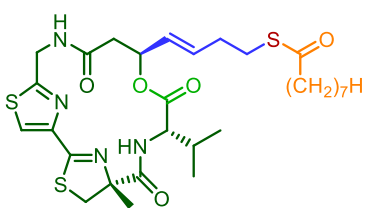

Largazole

Figure 2. Structure of the discussed cyclic depsipeptides. The colours represent the different parts highlighted in fig. 1 (the lighter green highlight the ester of the depsipetides), the orange colour represents the prodrug moiety.

\section{Cyclic tetrapeptides (Fig. 3)}

\section{(1-Alanine)-chlamydocin}

Chlamydocin was first isolated from the fungus Diheterospora chlamydospora in 1974 by Closse et al. ${ }^{[53]}$ and was shown to exhibit cytostatic activity on P-815 mouse mastocytoma cells ${ }^{[54,55]}$ - with 
poor results in animals, ${ }^{[54]}$ and without any hypothesized mode of action. More recently, chlamydocin was identified as HDACi, ${ }^{[56,57]}$ and was shown to inhibit the proliferation in seven human cancer cell lines. ${ }^{[58]}$ The HDAC inhibition activity in A2780 ovarian cancer total cell lysates was concentrationdependent with an $\mathrm{IC}_{50}$ value of $1.3 \pm 0.5 \mathrm{nM}$. This translated, in intact cells, in a hyperacetylation of histones $\mathrm{H} 3$ and $\mathrm{H} 4$, with maximal levels at a concentration of $10 \mathrm{nM}$, already detectable $2 \mathrm{~h}$ after treatment. Chlamydocin induced growth inhibition of A2780 cells at $1 \mu \mathrm{M}$ after $24 \mathrm{~h}$; with arrest in $\mathrm{G}_{2} / \mathrm{M}$ and apoptosis. The latter was shown to involve caspase-dependent cleavage of $P 21^{\text {cipl/wafl }}$ and to be associated with proteasome-mediated degradation of survivin.

The closely related 1-alaninechlamydocin was isolated from a Great Lakes-derived fungal isolate, identified as Tolypocladium sp. in $2014,{ }^{[59]}$ and tested in two human pancreatic carcinoma cell lines, MIA PaCa-2 and Panc-1, as well as an immortalized human pancreatic ductal cell line, hTERT-HPNE. It showed potent antiproliferative and cytotoxic activities against MIA PaCa-2 with $\mathrm{GI}_{50}$ and $\mathrm{LC}_{50}$ values of 5.3 and $22 \mathrm{nM}$ respectively, and inhibited the proliferation of Panc-1 and hTERT-HPNE at low nanomolar concentrations. For the two latter, however, 1-alaninechlamydocin did not exhibit cytotoxicity up to $10 \mu \mathrm{M}$. Exposition of MIA PaCa-2 cells to the HDACi, led to a decrease of cells in the $G_{1}$ phase and an accumulation of cells in $G_{2} / M$, while showing signs of early stage apoptosis. HDAC inhibition activity with an $\mathrm{IC}_{50}$ of $6.4 \mathrm{nM}$ is close to the potency observed in live cells, suggesting that it is the major mode of action responsible for the in vitro biological effects.

\section{Trapoxin}

Trapoxin A (also known simply as Trapoxin) and Trapoxin B were isolated from a fermentation broth of the fungus Helicoma ambiens in 1990 by Itazaki et al. and were reported to induce the morphological reversion from transformed to normal in sis oncogene-transformed NIH3T3 cells. ${ }^{[60]}$ In 1993, Kijima et al. showed that Trapoxin is an inhibitor of mammalian HDAC, observing an increase of histone acetylation in cells and the inhibition of partially purified mouse HDAC from FM3A cells. ${ }^{[18]}$ The inhibition was found to be irreversible, as the enzyme treated with trapoxin did not recover its activity after $18 \mathrm{~h}$ of dialysis. Additionally, it was found that the HDACi induced specific arrest of the cell cycle of rat $3 \mathrm{Y} 1$ fibroblasts in both $\mathrm{G}_{1}$ and $\mathrm{G}_{2}$ phases. 
Although epoxiketones are commonly thought to be irreversible HDAC inhibitors, as demonstrated by its use for the first isolation of HDAC $1,{ }^{[19]}$ trapoxin has been found to reversibly inhibit HDAC6. ${ }^{[57]}$ The tight binding was thought to result from the reaction of the epoxide moiety, however Porter et al. showed that it is the ketone moiety that undergoes a nucleophilic attack to form a zinc-bound tetrahedral gem-diolate, leaving the epoxide moiety intact. ${ }^{[61]}$

The closely related FR225497, described in $2000,{ }^{[62]}$ showed nanomolar range inhibition of partially purified human HDAC and antitumor activity in human T-cell leukemia Jurkat cells and human colon adenocarcinoma HT-29 cells, with $\mathrm{IC}_{50}$ of 152 and $158 \mathrm{ng} / \mathrm{mL}$ respectively.

\section{HC-Toxin}

Isolated in 1971 from the fungus Helminthosporium carbonum ${ }^{[63]} \mathrm{HC}$-Toxin was shown to be an inhibitor of yeast, plant and mammal HDAC ${ }^{[64]}$ and has been used successfully against breast cancer cells, ${ }^{[65,66]}$ neuroblastoma (NB) cells, ${ }^{[67,68]}$ and intrahepatic cholangiocarcinoma cells (ICC). ${ }^{[69]}$

Deubzer et al. observed that "nanomolar doses of HC-Toxin $\left(\mathrm{IC}_{50}<20 \mathrm{nM}\right)$ induce $\mathrm{G}_{0} / \mathrm{G}_{1}$-cell cycle arrest and apoptosis in both established NB cell lines and primary cell cultures but not in primary human fibroblasts". ${ }^{[67]}$ Additionally, the authors determined that treatment with HC-Toxin induces neuronal and neuroendocrine differentiation, and suppresses the invasive growth of NB cells, overall demonstrating an activation of the retinoblastoma tumour suppressor network in NB cells.

In the case of ICC, the screening of 34 HDACi showed that HC-Toxin exhibited the highest antitumor activity, inhibiting the cell proliferation and clone formation ability of the targeted cells, which was associated with an increase in the acetylation of $\mathrm{H} 4{ }^{[69]}$ The authors also observed an arrest of the cell cycle at the $\mathrm{G}_{0} / \mathrm{G}_{1}$ stage and an increase in apoptotic cell, as well as morphological changes, potentially indicating cell differentiation due to HC-Toxin.

\section{FR235222}

FR235222 was first isolated from a fungus, Acremonium sp. No. 27082, in 2003 by Mori et al. ${ }^{[0]}$ After determining and measuring its inhibitory activity on mammalian HDAC, the authors showed the activity of the HDACi as immunosuppressant, both in vitro ${ }^{[70]}$ and in vivo ${ }^{[71]}$ which was further studied by Matsuoka et al in 2007. ${ }^{[72]}$ Petrella et al. showed in $2008{ }^{[73]}$ that, at $50 \mathrm{nM}$, FR235222 
induces the accumulation of acetylated histones $\mathrm{H} 4$ and inhibits cell proliferation of human promyelocytic leukaemia U937 cells, human chronic myelogenous leukaemia K562 cells and human T cell leukaemia Jurkat cells, while having no effect on apoptosis. The antiproliferative activity of the inhibitor was linked to its ability to cause growth inhibition at the $\mathrm{G}_{0} / \mathrm{G}_{1}$ phase transition of cell cycle, and was postulated to be, at least partially, linked to an increase in the expression of Annexin A1 (ANXA 1). At higher concentration $(0.5 \mu \mathrm{M})$, FR23522 induced apoptosis in all three cell lines.

Later work of the group in 2010 with human prostate adenocarcinoma LNCaP cells, ${ }^{[74]}$ showed an increase in the acetylation of histone $\mathrm{H} 4$ as well as apoptosis through a caspase-dependent mechanism at a concentration of $0.5 \mu \mathrm{M}$, and an increase in the expression of ANXA1. It is worth noting that after siRNA-mediated inhibition of the expression of the latter, the apoptotic potency of the HDACi was only partially reduced.

\section{Microsporin A}

Isolated from the cultured marine-derived fungus identified as Microsporum cf. gypseum (along with Microsporin B), Microsporin A showed interesting in vitro cytotoxicity against human colon adenocarcinoma HCT-116 ( $\left.\mathrm{IC}_{50} 0.6 \mu \mathrm{g} / \mathrm{mL}\right)$ and a mean $\mathrm{IC}_{50}$ value of $2.7 \mu \mathrm{M}$ on 60 cell lines. ${ }^{[75]} \mathrm{In}$ vitro, on HeLa cell nuclear extract, Microsporin A inhibited a mixture of HDACs and HDAC8 with an $\mathrm{IC}_{50}$ of $0.14 \mu \mathrm{M}$ and $0.55 \mu \mathrm{M}$ respectively.

\section{Apicidins}

Apicidin and Apicidin A were first isolated by Darkin-Rattray et al. in 1996 from fermentations of fungal Fusarium spp. (ATCC 74289, ATCC 74322) and shown to have antiprotozoal activity, through their low nanomolar inhibitory effect on protozoal HDAC. ${ }^{[7]}$ More apicidins were isolated further on: $\mathrm{B}$ and $\mathrm{C}$ by in $2001,{ }^{[77]} \mathrm{D}_{1-3}$ in $2002,{ }^{[78]} \mathrm{E}$ in $2010,{ }^{[79]}$ and $\mathrm{F}$ in $2013 .{ }^{[80]}$ Among them, apicidin, apicidins A and D1 were reported to inhibit HDACs in HeLa cell extracts with $\mathrm{IC}_{50}$ values of 1, 2 and $0.3 \mathrm{nM}$ respectively. ${ }^{[78]}$ While apicidin was reported to selectively inhibit HDAC 2,3 and $8,\left(\mathrm{IC}_{50}\right.$ of 120,43 , and $575 \mathrm{nM}$ respectively), ${ }^{[81]}$ it also reduced the expression of HDAC3 and 4 in endometrial cancer cells, ${ }^{[82]}$ and inhibited the expression of HDAC4 and 7 in ovarian cancer cells, ${ }^{[83]}$ and in salivary mucoepidermoid carcinoma cells. ${ }^{[84]}$ Apicidin inhibited proliferation of various cancer cell 
lines, through the increase in the expression of $P 21^{\text {WAFI/Cipl }}$ and gelsolin, ${ }^{[85]}$ and, in human acute promyeolcytic leukemia cells HL60, through the selective induction of Fas/Fas ligand, resulting in the activation of caspase-3 and 9. ${ }^{[86]}$ Cheong et al. in 2003 studied the effect of apicidin in human BcrAbl-positive leukemia K562 cells and found similar activation of caspase-3 and 9 without the involvement of Fas/Fas ligand death receptor pathway. ${ }^{[87]}$ In endometrial and ovarian cancer cells, Ueda et al. observed strong anti-growth activity of apicidin, with the induction of apoptosis occurring in concert with the increase in levels of P21 $1^{\mathrm{WAF} 1}, \mathrm{P} 27^{\mathrm{KIP} 1}$ and the decrease of cyclin A and Ecadherin. ${ }^{[88]}$ Ahn et al. also reported the inhibition of the migration of human ovarian cancer cells via HDAC4 silencing, ${ }^{[83]}$ and the anti-tumour effect of apicidin on Ishikawa human endometrial cancer cells, in vitro and in vivo, ${ }^{[82]}$ through an increase in the acetylation of histones $\mathrm{H} 3$ and $\mathrm{H} 4$, leading to the up-regulation of $P 21$ and the decrease of cyclins A, B1, D1 and E, and CDK2 and 4. ${ }^{[89]}$

In 2011, Ahn et al. reported that apicidin induced apoptosis, through up-regulation of $P 21^{W A F I}$, and autophagy in human oral squamous carcinoma cells, ${ }^{[0]}$ while cell growth inhibition of salivary mucoepidermoid carcinoma cells was hypothesized to be mediated by the inhibition of IGF-1R, an upstream regulator of MAPK and AKT/mTOR, signaling pathways involved in cell survival and proliferation events. ${ }^{[91]}$

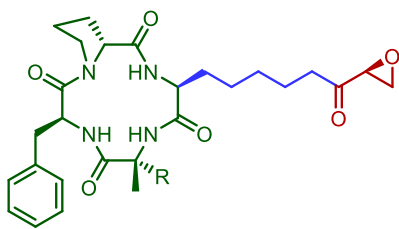

Chlamydocin, $\mathrm{R}=\mathrm{Me}$ 1-Alaninechlamydocin, $\mathrm{R}=\mathrm{H}$<smiles>C[C@@H]1NC(=O)[C@H]2CCN2C(=O)[C@H](CCCCCC(=O)C2CO2)N[C@@H](C)NC1=O</smiles>

$\mathrm{HC}$ toxin
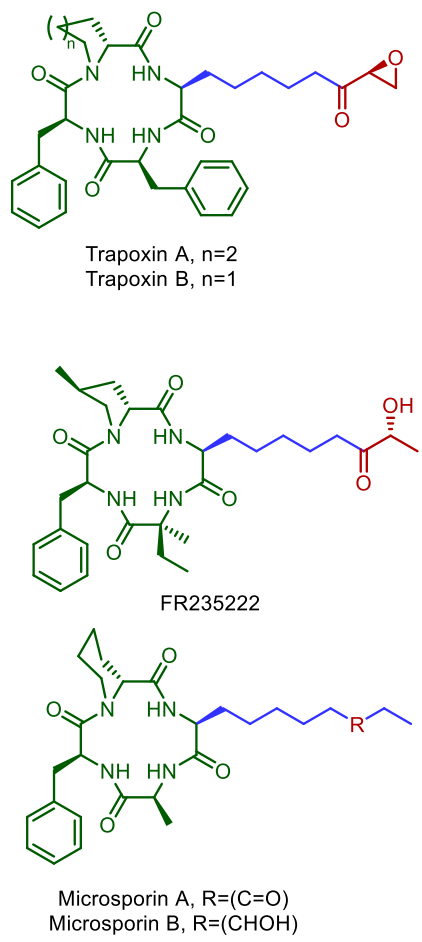

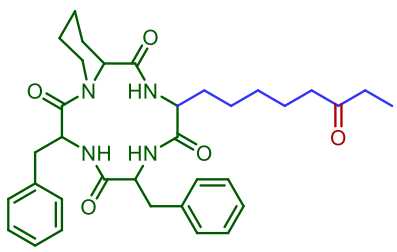

FR225497

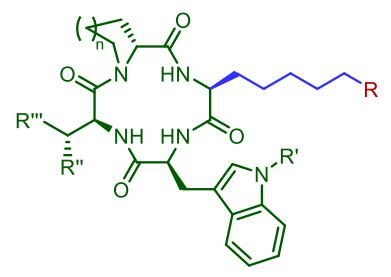

Apicidin, $\mathrm{n}=2, \mathrm{R}=\mathrm{COEt}, \mathrm{R}^{\prime}=\mathrm{OMe}, \mathrm{R}^{\prime \prime}=\mathrm{Et}, \mathrm{R}^{\prime \prime}=\mathrm{Me}$ Apicidin $A, n=2, R=C O E t, R^{\prime}=H, R^{\prime \prime}=E t, R^{\prime \prime \prime}=M e$ Apicidin $A, n=2, R=C O E t, R^{\prime}=H, R=E t, R "=M e$
Apicidin $B, n=1, R=C O E t, R^{\prime}=O M e, R^{\prime \prime}=E t, R^{\prime \prime}=M e$ Apicidin $C, n=2, R=C O E t, R^{\prime}=O M e, R^{\prime \prime}=M e, R^{\prime \prime \prime}=M e$ Apicidin $\mathrm{D}_{1}, \mathrm{n}=2, \mathrm{R}=\mathrm{COCH}(\mathrm{OH}) \mathrm{Me}, \mathrm{R}^{\prime}=\mathrm{OMe}, \mathrm{R} "=\mathrm{Et}, \mathrm{R} "{ }^{\prime}=\mathrm{Me}$ Apicidin $\mathrm{D}_{2}, \mathrm{n}=2, \mathrm{R}=\mathrm{CH}(\mathrm{SOH}) \mathrm{Et}, \mathrm{R}^{\prime}=\mathrm{OMe}, \mathrm{R}=\mathrm{Et}, \mathrm{R}^{\prime \prime}=\mathrm{Me}$ Apicidin $\mathrm{D}_{3}, \mathrm{n}=2, \mathrm{R}=\mathrm{CH}_{2} \mathrm{CH}(\mathrm{OH}) \mathrm{Me}, \mathrm{R}^{\prime}=\mathrm{OMe}, \mathrm{R}=\mathrm{Et}, \mathrm{R}^{\prime \prime}=\mathrm{Me}$ Apicidin $\mathrm{E}, \mathrm{n}=2, \mathrm{R}=n \mathrm{Pr}, \mathrm{R}^{\prime}=\mathrm{OMe}, \mathrm{R}=\mathrm{Et}, \mathrm{R} \mathrm{H}^{\prime \prime}=\mathrm{Me}$ Apicidin $F, n=2, R=C O O H, R^{\prime}=O M e, R^{\prime \prime}=P h, R^{\prime \prime}=H$ 
Figure 3- - Structure of the reported cyclic peptides. The colours represent the different parts

$$
\text { highlighted in fig. } 1
$$

Table 2. Selected examples of targeted genes by cyclic HDACi.

\begin{tabular}{c|l|l}
\hline Compound & \multicolumn{1}{|c|}{ Cell line } & \multicolumn{1}{c}{ Targeted genes } \\
\hline Spiruchostatin A,B & U937 (lymphoma) & Fas, caspase-3, 8, Bid \\
Thailandepsin A & 8505C (anaplastic thyroid cancer) & $P 21^{\text {WAFI }}, P 27^{\text {Kipl }}$, survivin, BCL-2 \\
Largazole & NB4 (leukemia) & $P 21^{\text {WAFICIPI }}$ \\
& HCT116 (colorectal carcinoma) & $P 21, P 19, P 15, P 57$, CDK6, cyclin D \\
& A549 (adenocarcinoma) & caspase-3, 9, P21, P27 \\
Chlamydocin & A2780 (ovarian carcinoma) & caspase-3, P21 $1^{\text {cipl/wafl }}$ \\
HC-Toxin & BE(2)-C (neuroblastoma) & N-myc, Skp2, Mad2, survivin \\
FR235222 & LNCaP (adenocarcinoma) & caspase-3, ANXA1 \\
Apicidin & Ishikawa (endometrial adenocarcinoma) & $P 21^{\text {WAFI }, P 27^{K I P I}, \text { cyclin A, E-cadherin }}$ \\
\hline
\end{tabular}

\section{Linear HDACi (Fig. 4)}

\section{Trichostatin A}

Isolated from the fungus Streptomyces hygroscopicus in 1976 by Tsuji et al., ${ }^{[92]}$ is a classic linear hydroxamic acid derivative and one of the first natural product determined to have HDAC inhibitory activity. ${ }^{[17]}$ Because it is one of the most potent known HDAC inhibitors, ${ }^{[93]}$ with nanomolar inhibition of recombinant HDAC 1 and $6,{ }^{[46]}$ trichostatin A (TSA) is routinely used as a positive control and as a reference to compare other HDACi. ${ }^{[46,67]}$ TSA has been reported to inhibit cell growth in, among others, lung adenocarcinoma, hepatoma, cervix carcinoma, and small cell lung cancer, through regulation $P 2 I^{\text {waffcipl }}, P 27, B c l$-Xl, cyclin A and E, etc. ${ }^{[94,95]}$ It is worth noting that the hydroxamate moiety has been shown to display mutagenicity, potentially limiting its clinical use. ${ }^{[96]}$

\section{Depudecin}

Discovered in the culture broth of the fungus Alternaria brassiciola in 1992, depudecin was determined by Kwon et al. in 1998 to have an inhibitory effect on HDAC in vitro, with an $\mathrm{IC}_{50}$ of 4.7 $\mu \mathrm{M}$ on purified FLAG epitope-tagged HDAC1. ${ }^{[97]}$ Depudecin was also shown to induce morphological changes in NIH3T3 fibroblasts transformed with v-ras and v-src oncogenes and to induce a hyperacetylation of histones in vivo.

Linear sulfides, disulfides, thiols

\section{Psammaplins}


Psammaplin A was first isolated in 1987 from an unidentified marine sponge ${ }^{[98]}$ and later on from other sources such as Thorectopsamma xana ${ }^{[99]}$. It consists of a symmetrical bromotyrosinederivative. The dimeric form, bisaprasin, as well as a large variety of related psammaplins (B-J), ${ }^{[99,100]}$ were reported to exhibit high inhibitory potency against $\mathrm{HDACs}$, with $\mathrm{IC}_{50}$ values ranging from 2.1 to $327 \mathrm{nM}$, with psammaplins $\mathrm{A}$ and $\mathrm{F}$ and bisaprasin being the most potent at 2.1, 4.2, and $9 \mathrm{nM}$. The trend is mirrored in the activation of $P 21$ promoter regions in cancer cells. ${ }^{[100]}$ Psammaplin A inhibited cell growth in monolayers of lung tumour A549 cells and breast tumour MDA-MB-435 cells, with $\mathrm{IC}_{50}$ values of 1.35 and $1.15 \mu \mathrm{M}$, and in vivo, with tumour inhibition in the A549 lung xenograph mouse model, with low toxicity.

Ahn et al. found that psammaplin A inhibited proliferation of on human endometrial cancer cells with an $\mathrm{IC}_{50}$ value of $5 \mu \mathrm{g} / \mathrm{mL} .^{[101]}$ At this concentration, it dramatically increased the levels of acetylated $\mathrm{H} 3$ and $\mathrm{H} 4$ histones, while $1 \mu \mathrm{g} / \mathrm{mL}$ caused the accumulation of cells at the $\mathrm{G}_{1}$ phase. This was correlated with the increased expression of $P 21^{W A F 1}$ and a decrease in the P53 levels. Additionally, treatment with the inhibitor caused an increase in apoptosis, with values of $50 \%$ after $48 \mathrm{~h}$ at $5 \mu \mathrm{g} / \mathrm{mL}$.

Psammaplins have been shown to inhibit cell growth and possess cytotoxic properties in the low micromolar range in a broad range of human cell lines, such as lung, ovarian, skin, colon, and breast cancer. ${ }^{[99]}$

\section{Allium organosulfur compounds}

The vegetables of the Allium genus, such as onions, garlic, scallion, leek and chives, are known for their medical benefits, which are attributed primarily to organosulfur compounds (OSC) released upon processing. ${ }^{[102]}$ These OSC include allicin, alliin, allyl mercaptan (AM), diallyl disulfide (DADS), and S-allylmercapto-L-cystein (SAMC), among others. It is hypothesized that Allium OSCs might be "funnelled" by metabolization to generate the actual HDAC inhibitors, such as AM, although it seems more than likely that the resulting thiols also react with other proteins. ${ }^{[103]}$

Amongst the most studied of the OSCs, DADS has been for example shown to increase the acetylation of histone H3 in human colon tumour cell lines Caco-2 and HT-29, ${ }^{[104]}$ and H4 in the former, accompanied by the up-regulation of $P 2 I^{\text {WAFI/CIP1 }[105]}$ and CDKN1A. ${ }^{[106]}$ The authors also found that 
AM inhibited HDAC activity stronger than its dimeric counterpart DADS (92\% against $29 \%) .{ }^{[00]}$ In breast cancer cell line MCF-7, DADS induced the hyperacetylation of histone H4, the activation of caspase-3, and the modulation of BAX, BCL-2, BCL-xL, and BXL-w, suggesting the involvement of the BCL-2 family proteins in the DADS-induced apoptosis. ${ }^{[107]}$ Zhao and coworkers reported in 2006 that DADS led to hyperacetylation of histones $\mathrm{H} 3$ and $\mathrm{H} 4$ and the up-regulation of $P 21^{\text {WAFl }}$ in human acute myeloid leukaemia HL-60 cells in vitro and in vivo. ${ }^{[108]}$

Allyl mercaptan (AM) is believed to be the metabolite of most OSCs, ${ }^{[109]}$ and has often been studied alongside DADS and reported as a HDACi. ${ }^{[105]}$ For example, DADS and AM induced histone H4 acetylation in HTC in rat hepatoma cells, T47D human breast cancer cells and DS19 mouse erythroleukemic cells, ${ }^{[110,111]}$ Nian et al. reported in 2008 that AM functioned as a competitive inhibitor of HDAC8 $\left(K_{\mathrm{i}}=24 \mu \mathrm{M}\right)$ and caused hyperacetylation of histones $\mathrm{H} 3$ and $\mathrm{H} 4$ in human colon cancer cells. ${ }^{[112]}$ The authors observed the presence of hyperacetylated histone $\mathrm{H} 3$ on the $P 21^{\text {WAFI }}$ gene promoter and increased binding of the transcription factor SP3. The induction of $P 21^{W A F I}$ protein expression coincided with growth arrest in the $\mathrm{G}_{1}$ phase of the cell cycle.

S-allylmercapto-L-cystein (SAMC) was reported to inhibit cell proliferation of DS19 mouse erythroleukemia cells with significant inhibition already at $0.5 \mu \mathrm{M}^{[113]}$ and an increase of the acetylation of histone $\mathrm{H} 4$.

\section{Bis(4-hydroxybenzyl)sulfide}

Isolated from an extract of Pleuropterus ciliinervis by Son et al in 2007, ${ }^{[14]}$ bis(4hydroxybenzyl)sulfide has been shown to have an in vitro inhibitory HDAC activity on HeLa nuclear extracts, with an $\mathrm{IC}_{50}$ value of $1.43 \mu \mathrm{M}$, as well as growth inhibitory activities on six different human tumour cell lines, namely ACHN (kidney), NCI-H23 (lung), PC-3 (prostate), MDA-MB-231 (breast), LOX-IMVI (melanoma), and HCT-15 (colon), with GI $_{50}$ values ranging from 1.45 (for MDA-MB231) to $>10 \mu \mathrm{M}$ for NCI-H23. ${ }^{[14]}$

\section{Sulforaphane and other isothiocyanates}

Abundantly found in cruciferous vegetables, such as cauliflower, cabbage, broccoli or Brussel sprouts, isothiocyanates (ITC) result from the hydrolysis of glucosinates by the plant enzyme mirosinase. ${ }^{[15]}$ 
Among the most studied ITC are found sulforaphane (SFN), allyl isothiocyanate (allyl-ITC), benzyl isothiocyanate (BITC) and phenethyl isothiocyanate (PEITC). In silico and in vitro experiments suggest that the active form of SFN, and potentially other ITC, is the metabolite sulforaphanecysteine. ${ }^{[116,117]}$ Surprisingly, although SFN has been extensively studied, its HDAC inhibitory activity had never been studied in a cell-free system until 2018, when Choi et al. determined that it inhibited HDAC 2 and 9, with $\mathrm{IC}_{50}$ values of 36 and $0.6 \mu \mathrm{M}$ respectively, while exhibiting much lower potency for HDAC 4, 5 and 7. ${ }^{[18]}$

SFN has been reported to inhibit cell growth, induce $\mathrm{G}_{2} / \mathrm{M}$ cell cycle block and increase expression of cyclin B1 in four different human breast cancer cells. ${ }^{[119]}$ In one of these cell lines (MDA-MB-231) apoptosis seemed to be initiated through induction of Fas ligand, resulting in the activation of caspase3 and 8, while in the others, apoptosis was initiated by decreased $\mathrm{Bcl}-2$ expression, release of cytochrome $c$ and activation of caspase- 3 and 9 but not 8 . Interestingly SFN inhibited HDAC activity and reduced the expression of estrogen receptor- $\alpha$, among others, although no change in the acetylation of histones $\mathrm{H} 3$ or $\mathrm{H} 4$ was observed.

Myzak et al. found that, when consumed in the diet at an average daily dose of $7.5 \mu \mathrm{mol}$ per animal for 21 days, SFN suppressed the growth of xenografts of human PC-3 prostate cancer cells by $40 \%$ in mice, accompanied by significant decrease in HDAC activity in the xenografts. ${ }^{[120]}$

PEITC was found to act as a de-repressor of the $P 21$ promoter in $\mathrm{LNCaP}$ androgen-dependent prostate cancer cells in 2008 by Wang and coworkers. ${ }^{[121]}$ Treatment of the cells resulted in cell cycle arrerst and P53-independent up-regulation of, among others, $P 21^{\text {WAFI }}$ and P27. PEITC caused histone hyperacetylation, which was associated with the $P 21$ gene, as found by immunoprecipitation. Interestingly, PEITC also significantly down-regulated c-MYC, a repressor of $P 21$.

Interestingly BITC causes $\mathrm{G}_{2} / \mathrm{M}$ cell cycle arrest and apoptosis in human pancreatic cancer cells. The authors observed a $60 \%$ inhibition in cell growth at concentrations of 5-10 $\mu \mathrm{M}$, whereas higher concentrations did not significantly increase this value. Treatment with BITC resulted in increased levels of caspase- 3 and $P 2 I^{W A F I / C I P I}$, and down-regulation of $\mathrm{G}_{2} / \mathrm{M}$ regulatory proteins, such as cyclin $\mathrm{B} 1, \mathrm{CDC} 2$ and $\mathrm{CDC} 25 \mathrm{C} .^{[122]}$ 
<smiles>C=CC(O)C1O[C@@H]1/C=C/[C@@H]1O[C@@H]1[C@H](C)O</smiles>

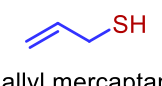

allyl mercaptan<smiles>CS(=O)CCCCN=C=S</smiles>

sulforaphane

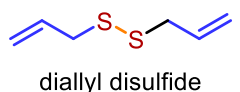

diallyl disulfide

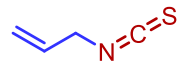

allylisothiocyanate

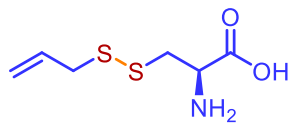

s-allylmercapto-I-cystein

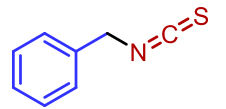

benzylisothiocyanate
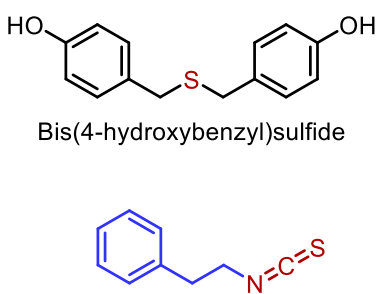

Phenethyl isothiocyanate

Figure 4. Structure of the discussed linear inhibitors. The colours represent the different parts highlighted in fig. 1.

\section{Non-Zinc Binding Inhibitors (Fig. 5)}

\section{Epicocconigrone A and epicoccolide B}

Isolated from the endophytic fungus Epicoccum nigrum in 2014, epicocconigrone A and epicoccolide

B were tested against total protein extracts of K-562 cells and against recombinant proteins and displayed a micromolar HDAC inhibitory activity, with $\mathrm{IC}_{50}$ values ranging from 1.6 to $12.9 \mu \mathrm{M} .^{[123]}$ Both compounds were tested for proliferation and viability of Burkitt's lymphoma RAJI and histiocytic lymophome U-937 cell lines. Epicocconigrone A inhibited 50\% of the proliferation of RAJI cells at $5 \mu \mathrm{M}$ and induced about $30 \%$ cell death at $25 \mu \mathrm{M}$, and had no effect on U-937 cell viability while inducing growth inhibition of $32 \%$ at $5 \mu \mathrm{M}$. Epicoccolide B had no effect on cell viability in any of the two cell lines, but inhibited the growth in RAJI and U-937 by 55\% and 30\% respectively at $25 \mu \mathrm{M}$, showing that both HDACi mostly act as cytostatic agents. Notably, neither had any effect on cell viability of healthy peripheral blood mononuclear cells (PBMCs).

\section{Zerumbone}

Zerumbone and 6-methoxy-2E,9E-humuladien-8-one are two sesquiterpenoids isolated from Zingiber zerumbet, a wild ginger from Southeast Asia, which display HDAC inhibitory activity. ${ }^{[124]}$ The compounds were tested against partially purified HDAC enzymes $\left(\mathrm{IC}_{50}\right.$ of 8.35 and $1.25 \mu \mathrm{M}$ respectively) and their antiproliferative effects using human prostate cancer PC-3 cells ( $\mathrm{GI}_{50}$ of 14.24 and $4.63 \mu \mathrm{M}$ respectively). Further investigations on six human tumour cell lines and one type of 
human primary cells (hepatocytes) showed that both compounds display an inhibitory effect on the tested cancer cells, although with a two- to ten-fold lower activity than SAHA and similar or increased cytotoxicity against hepatocytes.

\section{Ursolic acid}

Ursolic acid can be found in a wide variety of fruit and herbs used in daily life, and in large amounts in apple peels. This triterpenoid has been shown, by Chen et al. in $2009,{ }^{[125]}$ to be cytotoxic to a selection of cancer cell lines, in particular to human gingival cancer Ca9-22 cells and human leukaemia HL60 cells, with $\mathrm{IC}_{50}$ values of 5.9 and $8.7 \mu \mathrm{g} / \mathrm{mL}$. The authors showed in a qualitative way that the activity of HDAC 1, 3, 4, 5 and 6 decreased upon treatment with increasing amounts of ursolic acid, and similarly, observed an increase in the acetylation of histone $\mathrm{H} 3$.

\section{Gymnochrome E}

Found in metabolites of the crinoid Holopus rangii, ${ }^{[126]}$ Gymnochrome E was shown to inhibit the proliferation of the multi-drug-resistant ovarian cancer cell line NCI/ADR-Res with an $\mathrm{IC}_{50}$ value of $3.5 \mu \mathrm{M}$, while showing no inhibitory effects on PANC-1 pancreatic carcinoma of DLD-1 human colorectal adenocarcinoma cell lines at a concentration of $6.4 \mu \mathrm{M}$. The compound was also found to inhibit HDAC1 with an $\mathrm{IC}_{50}$ of $10.9 \mu \mathrm{M}$.

\section{(Dehydro)cyclostellettamines}

In 2004, Oku et al. isolated from the aqueous extract of a marine sponge of the genus Xestospongia a family of molecules including cyclostellettamine A and G and dehydrocyclostellettamine D and E. The compounds showed moderate activity against HDAC from K562 cells (human chronic myeloid leukemia cell line), with $\mathrm{IC}_{50}$ values ranging from 17 to $80 \mu \mathrm{M}$, and good to moderate cytotoxicity against HeLa human cervix carcinoma ( IC $_{50}$ 0.6-2.8 $\mu \mathrm{M}$ ), P388 mouse leukemia ( $\mathrm{IC}_{50}$ 1.3-2.7 $\mu \mathrm{M}$ ), and $3 \mathrm{Y} 1$ rat fibroblastic cells $\left(\mathrm{IC}_{50} 3.2-11 \mu \mathrm{M}\right){ }^{[127]}$

\section{Flavonoids}

Apigenin is abundantly present in common fruits and vegetables such as grapefruit, parsley, chamomile and wheat sprouts, ${ }^{[128]}$ and has been shown to be an in vitro HDAC inhibitor, with an $\mathrm{IC}_{50}$ value of $27 \mu \mathrm{M}$ for class I HDAC and no observed inhibition of class IIa and IIb. ${ }^{[129]}$ In a 2012 study, 
Pandey et al. measured the effect of apigenin on human prostate cancer 22Rv1 and PC-3 cells and found a decrease in HDAC activity of $22 \%$ and $62 \%$ respectively at $40 \mu \mathrm{M}$ of apigenin. ${ }^{[128]}$ This decrease, however, was linked to a diminished expression of HDAC, at $40 \mu \mathrm{M}$ of apigenin: in $22 \mathrm{Rv} 1$, HDAC 1 and 3 levels were down by 52\% and 22\% respectively, while in PC-3, these values were of $46 \%$ and $48 \%$. Unsurprisingly, both effects together resulted in an overall increase in the acetylation of histones $\mathrm{H} 3$ and $\mathrm{H} 4$ in both cell lines. Apigenin was found to cause a marked decrease in the percentage of cells in the S-phase of the cell cycle, the treated cells being preferentially arrested in the $\mathrm{G}_{0} / \mathrm{G}_{1}$ phase, and to induce apoptosis.

Tseng et al. have more recently investigated the effects of apigenin in MDA-MB-231 breast cancer cells. It was found that the potential HDACi inhibits cell proliferation in the studied cells, with $40 \mu \mathrm{M}$ being defined as the "nonapoptotic induction concentration". ${ }^{[130]}$ The authors measured an increase in the acetylation of histone $\mathrm{H} 3$, in particular in the $P 21^{W A F I / C I P 1}$ promoter, while $\mathrm{H} 4$ appeared to not be affected by apigenin. In this case, however, the treated cells accumulated in the $G_{2} / \mathrm{M}$ cell phase, unlike what was observed in prostate cancer cells. The reduction upon treatment with apigenin of cyclin $\mathrm{A}$ and $\mathrm{B}$ and CDK1 levels, which modulate $\mathrm{G}_{2}$-to-M progression, is given as a possible explanation for this modulation of the cell cycle. Additionally, the authors observed a significant antitumor growth effect in vivo in nude mice with MDA-MB-231 cells orthotopically injected, without any sign of toxicity observed in the mice.

Kaempferol is synthesized by a variety of vegetables and fruits, such as tomatoes, hop, red grapes, grapefruit, strawberries and gingko biloba and can also be found as an ingredient in honey, and green and black tea. ${ }^{[131]}$ It was found to inhibit HDAC enzymes in vitro, with $\mathrm{IC}_{50}$ values of 39,48 and 29 $\mu \mathrm{M}$ for class I HDAC, 2a and 2b respectively. ${ }^{[129]}$ Similar values were found by Berger et al. in 2013 with all tested recombinant HDACs of class I, II and IV. ${ }^{[131]}$ The authors further tested kaempferol in human-derived hepatoma cell lines HepG2 and Hep3B, as well as HCT-116 colon cancer cells, and found that it caused a hyperacetylation of histone $\mathrm{H} 3$ in all cell lines. This translated in an antiproliferative activity, independently of the p53 status of the tested cell line, shown by the fact that HepG2 has wild-type p53 and Hep3B tumour cells are p53 deficient. 
Plants rich in luteolin have been used in Chinese traditional medicine and can be found in celery, broccoli, green pepper, parsley, dandelion, etc. ${ }^{[132]}$ Godoy et al. measured $\mathrm{IC}_{50}$ values ranging from 17 and $18 \mu \mathrm{M}$ for inhibition of class I, IIa and IIb HDAC, among the lowest for flavonoid derivatives. ${ }^{[129]}$ In 2011, Attoub et al. investigated the effect of luteolin in human epithelioid cancer cells, namely LNM35 (lungs), HT29 (colon), HepG2 (liver), MCF7/6 and MDA-MB231-1833 (breast). The authors observed the inhibitory effect of luteolin in vitro on HDAC in HeLa nuclear extracts, with $100 \mu \mathrm{M}$ doses of luteolin leading to a significant inhibition already visible after $6 \mathrm{~h}$ on both histones $\mathrm{H} 3$ and $\mathrm{H} 4$, with values around 20 and 30\% respectively. When incubating $24 \mathrm{~h}$, these values increased to around 80 and $40 \%$. When using $50 \mu \mathrm{M}$ doses, a significant activity of about $30 \%$ could be observed on histone $\mathrm{H} 3$, but only after $24 \mathrm{~h}$. Luteolin also exhibited an effect on cell viability and apoptosis in all tested cell lines, with $\mathrm{IC}_{50}$ values of 60,65 and $90 \mu \mathrm{M}$ for HepG2, LNM35 and MCF7/6, respectively, and more than $200 \mu \mathrm{M}$ for HT29 and MDA-MB231-1833. Further analysis on the LNM35 cell line showed that treatment with $50 \mu \mathrm{M}$ luteolin induced apoptosis of $20 \%$ of the cells, associated with a four-fold increase in caspase $3 / 7$ activity. Finally, the authors determined that luteolin could efficiently impair the invasiveness of MCF-7/6 cells in the chick heart invasion model effects at $10 \mu \mathrm{M}$ concentration, while not exhibiting any detectable toxic effect on the heart tissue.

Chrysin is found in honey, propolis and passion flowers among others, ${ }^{[133]}$ and has been found to weakly inhibit HDAC 2 and 8 in vitro ( IC $_{50}$ of 129 and $40 \mu \mathrm{M}$ respectively) out of HDAC 1-11. ${ }^{[134]}$ When treating breast cancer MDA-MB-231 cells with $40 \mu \mathrm{M}$ of chrysin, Sun et al. have observed a significant increased of the expression of $P 21^{W A F I / C I P 1}$ and an inhibition of cell proliferation, with no signs of cell death, suggesting that the suppression occurred through the induction of differentiation. This translated, in vivo, in the inhibition of tumour growth in mice with MDA-MB-231 cell xenograft. ${ }^{[134]}$ Pal-Bhadra et al. also observed inhibition of HDAC 2 and 8 in melanoma A375 cells, although concomitant with a decrease in HDAC expression, leading to increase acetylation of histones $\mathrm{H} 3$ and $\mathrm{H} 4$ and activation of $P 2 I^{\text {WAFI/CIPI }} \cdot{ }^{[135]}$ As a result, chrysin induced accumulation of cells in the $\mathrm{G}_{1}$ phase and apoptosis through downregulation of anti-apoptotic $\mathrm{Bcl}-\mathrm{xL}$ and survivin and 
upregulation of caspase-3. In breast cancer cells, Sun et al. did not observe significant cell cycle arrest at any phase. ${ }^{[134]}$

Osajin and pomiferin have been isolated from the ground fruit of Maclura pomifera (or the Osage orange) by Son et al. in 2007. ${ }^{[136]}$ Their inhibitory HDAC activity was determined on HeLa nuclear extracts, with $\mathrm{IC}_{50}$ values of 6.53 and $1.05 \mu \mathrm{M}$, respectively. The compounds were tested against a range of cancer cell lines, namely ACHN (kidney), NCI-H23 (lung), PC-3 (prostate), MDA-MB-231 (breast), LOX-IMVI (melanoma), HCT-15 (colon) and hepatocytes as human primary cells, displaying growth inhibitory activities in all of them. Osajin $\mathrm{GI}_{50}$ values ranged from 9.65 to $13.32 \mu \mathrm{M}$, while pomiferin shower more potency, with values ranging from 1.32 to $5.14 \mu \mathrm{M}$. The toxicity on hepatocytes showed the same trend, with a $\mathrm{GI}_{50}$ of $>500 \mu \mathrm{M}$ for osajin and $123 \mu \mathrm{M}$ for pomiferin.

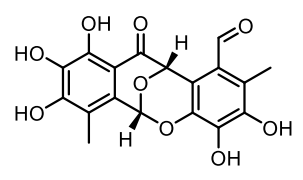

Epicocconigrone $\mathrm{A}$

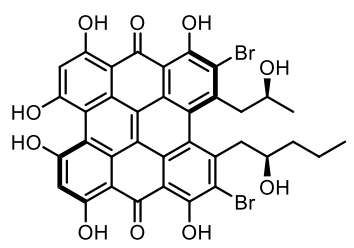

Gymnochrome E

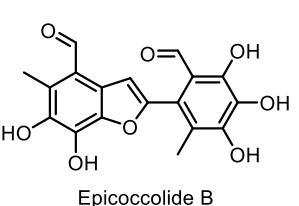

Epicoccolide B

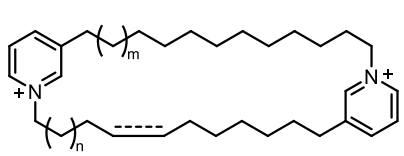

Cyclostellettamine $A, m=1, n=2$ Cyclostellettamine $\mathrm{G}, \mathrm{m}=1, \mathrm{n}=1$ Dehydrocyclostellettamine $D, m=1, n=4, \Delta^{13}$ Dehydrocyclostellettamine $E, m=2, n=4, \Delta^{13}$

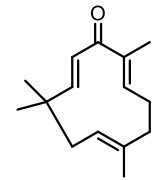

Zerumbone

6-methoxy-2E,9E-humuladien-8-one<smiles>C/C=C\C(=O)C(C)C(CC/C(C)=C/CC(C)(C)C)OC</smiles><smiles>[R]c1cc(-c2oc3cc(O)cc(O)c3c(=O)c2[R])cc([R])c1O</smiles>

Apigenin, $\mathrm{R}_{1}=\mathrm{H}, \mathrm{R}_{2}=\mathrm{H}, \mathrm{R}_{3}=\mathrm{H}$ Kaempferol, $\mathrm{R}_{1}=\mathrm{H}, \mathrm{R}_{2}=\mathrm{H}, \mathrm{R}_{3}=\mathrm{OH}$ Luteolin, $\mathrm{R}_{1}=\mathrm{H}, \mathrm{R}_{2}=\mathrm{OH}, \mathrm{R}_{3}=\mathrm{H}$
Chrysin, $\mathrm{R}_{1}=\mathrm{OMe}, \mathrm{R}_{2}=\mathrm{OMe}, \mathrm{R}_{3}=\mathrm{H}$

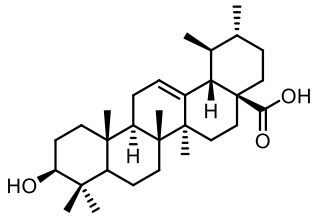

ursolic acid

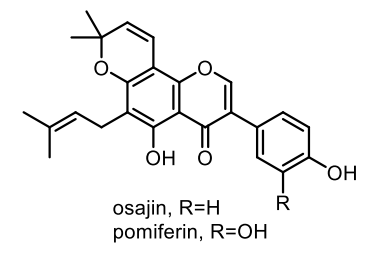

Figure 5- Structure of the reported non-zinc-binding inhibitors.

\subsection{For Class III HDAC inhibition}

Class III HDACs, sirtuins, are $\mathrm{NAD}^{+}$-dependant HDACs and do not contain a zinc cation in their active site. Therefore, sirtuins inhibitors are different structurally. SIRT1 and 2 are the most studied for inhibition in anticancer therapies ${ }^{[137]}$ or activation in other pathologies such as type 2 diabetes, inflammatory diseases and neurodegenerative disorders ${ }^{[138]}$. Few natural products were identified as sirtuin modulators.

Resveratrol was identified as a yeast SIR2 activator ${ }^{[139]}$ increasing yeast lifespan ${ }^{[140]}$ and a human SIRT1 activator inhibiting TNF-alpha induced inflammation in fibroblasts. ${ }^{[141]}$ However, the activator 
effects of resveratrol have been contested as no effect was detected in enzymatic assay with SIR2 [142] and the pharmacological effect of resveratrol was shown to be independent of SIRT1 in various models. ${ }^{[143]}$ In cancer resveratrol was shown to induce gastric cancer cell arrest in a SIRT1-dependant manner. ${ }^{[144]}$

Quercetin was also identified as SIRT1 acetylation activator in yeast but with no effect on lifespan. ${ }^{[140]}$ In HT29 colon carcinoma cells, its metabolite, quercetin 3-O-glucuronide, showed a weak inhibition of recombinant SIRT1 enzyme. ${ }^{[145]}$

Nicotinamide was shown to be a pan-sirtuin inhibitor ${ }^{[146,147]}$ repressing gastric cancer growth. ${ }^{[148]}$ However, due to the pleiotropic targets of nicotinamide it has probably several in-cell targets.

Tanikolide dimer is a dimer of the biologically active $\delta$-lactone Tanikolide. It was isolated from Lyngbya majuscula, a Madagascar marine cyanobacterium, and shown to inhibit SIRT2. The $\mathrm{IC}_{50}$ values range from $176 \mathrm{nM}$ to $2.4 \mu \mathrm{M}$ depending on the evaluation assay. ${ }^{[149]}$

More recently, Schnekenburger et al. showed that eurochevalierine, a metabolite from the fungus Neosartorya pseudofischeri, inhibits sirtuin 1 and 2 with $\mathrm{IC}_{50}=10 \mu \mathrm{M}$ with no effect on sirtuin 3 nor on a panel of class I and II HDACs. Eurochevalierine exhibit a sirtuin inhibitor profile in vitro in several cancer cell lines (SK-MEL-28, melanoma; U-373, glyoblastoma and A-549, adenocarcinoma) with increase of acetylation of sirtuin targets and without any toxicity for normal cells. They identified its mode of interaction with SIRT1 and SIRT2 by molecular docking. ${ }^{[150]}$

\subsection{For DNA methylation inhibition}

\section{Natural products altering DNA methylation}

DNMTs are enzymes responsible for methylation of cytosine in a CpG context, using $S$-adenosyl-Lmethionine (SAM) as a methyl donor. In cancers, hypermethylation of the promoter regions of tumour suppressor genes (TSGs) leads to their silencing, which participates to tumour formation and proliferation. As mentioned before the interest of finding non-nucleoside DNMTi remains a crucial challenge. Therefore testing natural products can highlight unexplored DNMTi chemical scaffolds. 
For several natural products (Fig. 6), a modification in DNA methylation in cancer cell lines was shown but no direct DNMT inhibition activity has been reported yet.
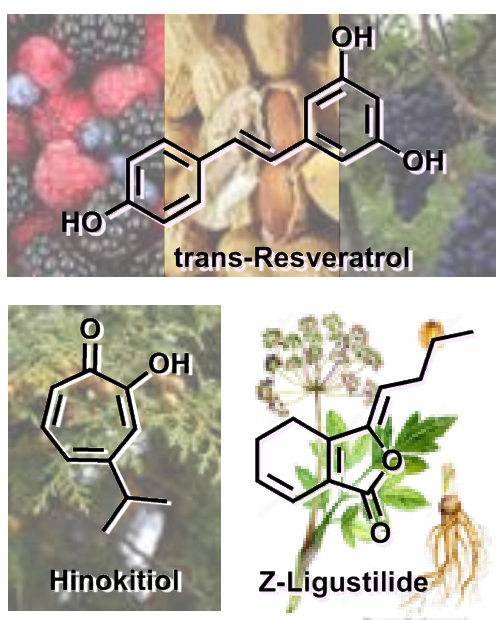

Ho
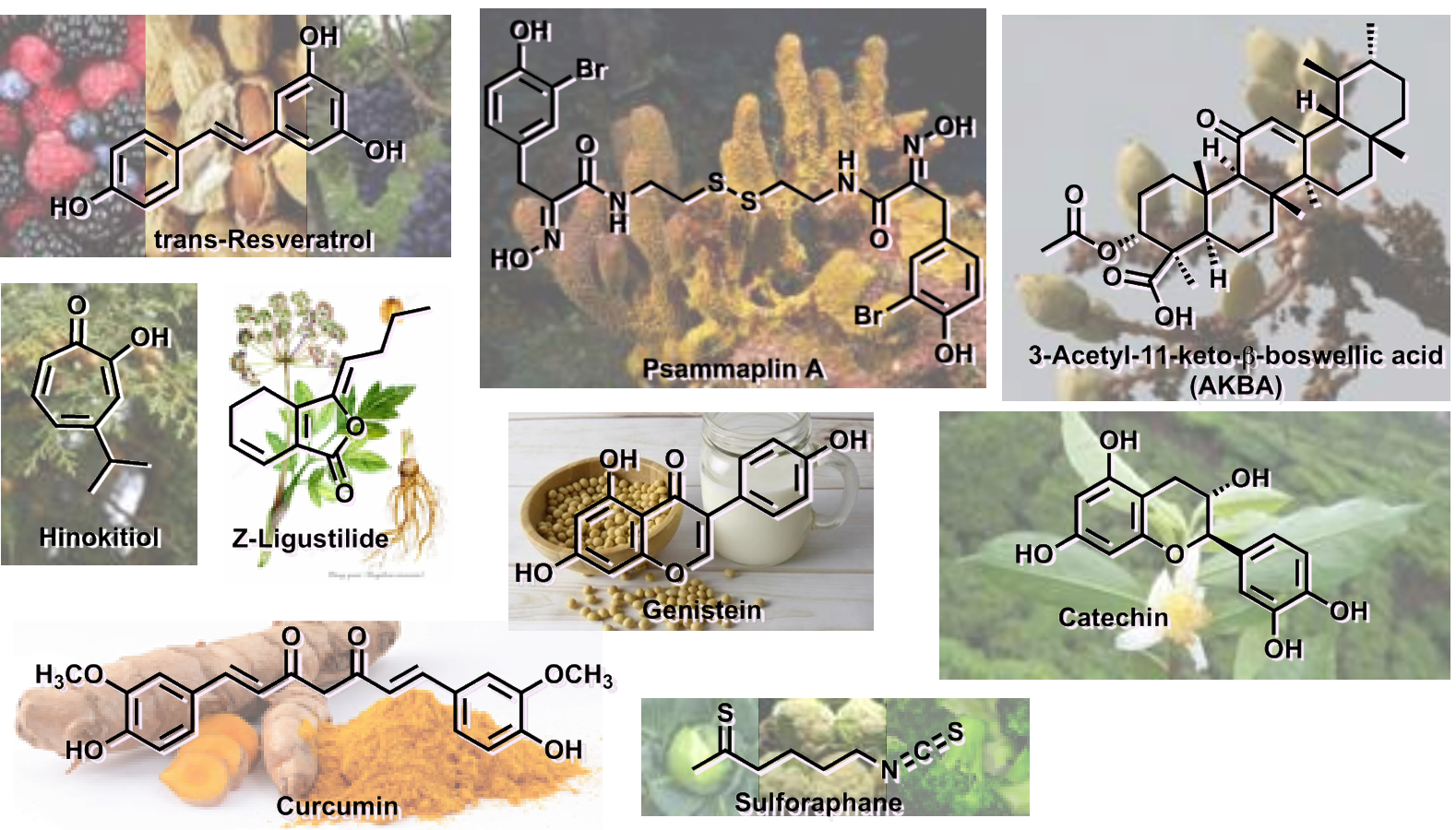

Figure 6: Structure of natural products altering DNA methylation

\section{Resveratrol}

Resveratrol (trans-3,5,4'-trihydroxystilbene) is a stilbene produced by red grapes, peanuts and berries as part of their defence system in response to an injury. This natural phenolic derivative was shown to decrease methylation of PTEN promoter and induce its reexpression in MCF7 breast cancer cell line. ${ }^{[151]}$ In combination with pterostilbene, another stilbene found in plants, resveratrol resulted in the down-regulation of DNMT3B in HCC1806 triple-negative breast cancer cells without any significant effects on control MCF10A breast epithelial cells. ${ }^{[152]}$ The expression of DNMTs and certain other associated protein, including HDAC1 and MeCP2 was decreased after treatment with resveratrol (10$15 \mu \mathrm{M})$ in MDA MB 231 and MCF7 breast cancer cell lines. ${ }^{[153]}$ A decrease in the overall DNA methylation level with $15 \mu \mathrm{M}$ of resveratrol was observed using nuclear extracts from HCC1806 cells. ${ }^{[152]}$ but no or very weak inhibition of DNMT was shown in vitro, which suggests an indirect mechanism of DNA methylation inhibition.

\section{Boswellic acids}


Boswellic acids are extracted from the plant Boswellia serrata. Among them the acetyl-11-keto- $\beta$ boswellic acid (AKBA), a pentacyclic terpenoid, is the major active derivative. It was shown to reduce DNA methylation at several CpG loci in SW48 colorectal cancer cell line and induce the up-regulation of gene expression including TSG such as SAMD14 and SMPD3. A global DNA methylation inhibition was measured in SW48 and SW480 colorectal cancer cell lines following AKBA treatment at $40 \mu \mathrm{M} \cdot{ }^{[154]}$ Although to date AKBA inhibition activity on purified DNMT was not reported, these results suggest that AKBA induce inhibition of DNA methylation via an indirect pathway.

\section{Hinokitiol}

Hinokitiol (4-isopropyltropolone) is extracted from the Chymacyparis obtusa tree. In colon cancer cell line HCT116, decreased DNMT1 and ubiquitin-like containing PHD and RING finger domains 1 (UHRF1) expressions and increased ten-eleven translocation methylcytosine dioxygenase 1 (TET1) expression were observed after treatment with $10 \mu \mathrm{M}$ of hinokitiol for 48 to $72 \mathrm{~h}$. TET1 is responsible for the conversion of 5-methylcytosine $(5 \mathrm{mC})$ in 5-hydroxymethylcytosine $(5 \mathrm{hmC})$ identified as the first step towards DNA demethylation. Following hinokitiol treatment, the global level of 5hmC was increased whereas the global $5 \mathrm{mC}$ level remained unchanged. However, looking more closely at specific genes, a decrease of methylation was reported for MGMT, CHST10 and BTG4 together with an increase of their expression. ${ }^{[155]}$

\section{Z-Ligustilide}

Z-Ligustilide is extracted from the Asian medicinal herb Radix Angelicae Sinensis (RAS) with cytotoxic effect against TRAMP1 C1 prostate cancer cell line at concentrations higher than $50 \mu \mathrm{M}$. ZLigustilide showed an alteration of the DNA methylation level in the NRF2 promoter and an increase of its expression in a concentration-dependent manner with no changes in DNMT or HDAC1-5 and 8 expression levels. The authors carried out enzymatic assays on M.SssI and reported for Z-Ligustilide an $\mathrm{IC}_{50}=1055 \square \mu \mathrm{M} .^{[156]}$ This can hardly be considered as an inhibitory effect, suggesting an indirect mechanism for DNA methylation inhibition by Z-ligustilide.

\section{Psammaplin A}


As mentioned earlier in this review, psammaplin A and derivatives were first isolated in 1987 from unidentified sponge ${ }^{[98]}$ and antibacterial and antitumour activities were reported. These compounds, later isolated from the Papua New Guinea sponge Pseudoceratina purpurea showed a nanomolar in vitro inhibition of DNMT1 together with HDAC inhibition. ${ }^{[100]}$ However this inhibition value was obtained using a partially purified DNMT, which could be the reason for the lack of activity measured by Baud and coworkers for DNMT1 inhibition. ${ }^{[157]}$

\section{Sulforaphane}

Sulforaphane (SFN) is an isothiocyanate isolated from cruciferous vegetables. After SFN treatment in MCF-7 and MDA-MB-231 cancer cell lines, the methylation status at CpG sites of the telomerase reverse transcriptase $h T E R T$ gene was altered and its mRNA transcription was down-regulated. This was observed concomitantly with a lower expression of DNMT1 and 3A together with a modification of histone acetylation levels. This suggested that the modification of DNA methylation level occurred via an indirect mechanism involving HDAC inhibition (vide supra) ${ }^{[158]}$ Another study reported that the treatment with SFN in LnCaP prostate cancer cell line resulted in a lower methylation of the promoter of cyclin D2, correlated with prostate cancer progression, which was associated with an increase of cyclin D2 expression. However a down-regulation of the DNMT1 and DNMT3B expression was also reported, which suggested as well an indirect pathway. ${ }^{[159]}$

\section{Catechin}

Catechin is a flavanol extracted from tea. In MCF7 and MDA-MB-231 breast cancer cell lines, catechin induced inhibition of the $R A R \beta$ gene promoter methylation similar to EGCG. Low cytotoxic effects were observed up to $50 \mu \mathrm{M} .{ }^{[160]}$ The inhibition activity of catechin against M.SssI and DNMT1 was weak since only $40 \%$ inhibition was achieved at the highest tested concentration (i.e. $20 \mu \mathrm{M}$ ). However in presence of COMT, catechin showed micromolar $\mathrm{IC}_{50}$ with $6.5 \mu \mathrm{M}$ and $4.6 \mu \mathrm{M}$ against M.SssI and DNMT1, respectively. ${ }^{[160]}$ This highlights the indirect mechanism of DNA methylation inhibition of catechin that is COMT-dependant, similarly to quercetin. Although its bioavailability seemed better, catechin was shown to be a good substrate for COMT, which results in an increase of SAH concentration due to their methylation metabolism. ${ }^{[161]}$ 


\section{Genistein}

Genistein (4',5,7-trihydroxyisoflavone) is the main isoflavonoid from soybean present in significant amounts in Asian diet. In rat, prepubertal genistein exposure resulted in the up-regulation of the TSG BRCA1. Although its expression is controlled by epigenetic mechanisms, no evidence was reported in this paper that could confirm genistein as an epi-target(s). ${ }^{[162]}$ Genistein was shown to induce the expression of $P 21^{W A F I / C I P I}$ and $P 16^{I N K 4 a}$ tumour suppressor genes in prostate cancer cells. This was identified to be the consequence of several chromatin modulations, i.e. decrease of DNA methylation in $P 21$ promoter and increase of histone acetylation $P 21$ and $P 16$ transcription start sites. ${ }^{[163]}$ Genistein was also shown to reverse hypermethylation and induce the reexpression of $P 16^{I N K 4 a}$, retinoic acid receptor $\beta(R A R \beta)$ and $M G M T$ genes carcinoma KYSE 510 cell line ${ }^{[164]}$ Genistein treatment induced a decrease of the methylation in promoter regions of GSTP1 gene in PC-3, DU145 and LNCaP prostate cancer cell lines and of EPHB2 gene in DU145 cell line associated with an increase of their expression. The same study, however, reported no effect on BRCAl methylation or expression. ${ }^{[165]}$ In breast cancer cell lines, genistein was suggested to decrease the GSTP1 promoter methylation and to increase its expression in MDA-MB-468 cells. ${ }^{[166]}$ Similar results were shown for BRCA1 and BRCA2 ${ }^{[167]}$ and ATM, APC, PTEN, SERPINB5 ${ }^{[168]}$ genes in MCF-7 and MDA-MB-231 cell lines. Molecular modelling shows that Genistein could interact within the DNMT1 active site, cytosine pocket. However, with about $40 \%$ inhibition of DNMT activity in nuclear extracts of MCF-7 and MDA-MB231 cell lines at $100 \mu \mathrm{M}$, genistein can not be consider as a potent inhibitor of DNMT. Moreover, genistein causes a decrease of DNMT1 expression that can be the cause of the observed lower DNA methylation level. Noteworthy, following genistein treatment, no significant alteration of DNMT3A and 3B expression was observed MCF-7 and MDA-MB-231 breast cancer cell lines ${ }^{[168]}$ but a decrease of DNMT3B expression was observed in Human neuroblastoma SK-N-SH cell line. ${ }^{[169]}$ Low DNA methylation inhibition activity was confirmed using KYSE 510 cell line nuclear extract ${ }^{[164]}$ and no inhibition activity was observed on Dnmt3A/3L complex ${ }^{[170]}$ indicating an indirect pathway of DNA methylation inhibition, especially since multiple targets were identified for genistein such as the inhibition of HDAC6 recruitment by decreasing Hsp90 activity, ${ }^{[171]}$ tyrosine specific protein

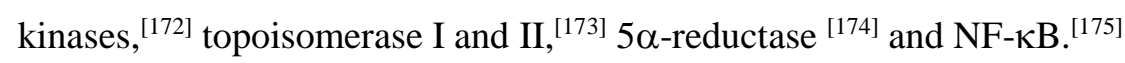




\section{Curcumin}

Curcumin (1,7-bis(4-hydroxy-3-methoxy-phenyl)-1,6-heptadiene-3,5-dione; diferuloylmethane) is the major flavonoid component of the rhizome of Curcuma longa (spice turmeric) that is used in the traditional Indian medicine. ${ }^{[176]}$ Curcumin has many pharmacological effects in cancers ${ }^{[177]}$ including the modulation of epigenetic mechanisms. ${ }^{[178]}$ Only a low effect of curcumin on the global DNA methylation level in HCT116, HL-60 and HEK293 cell lines were reported. ${ }^{[179]}$ In colorectal cancer cell lines, however, curcumin was reported to alter, in a time dependent-manner, the DNA methylation at a selected subset of loci contrarily to the 5-azadC that showed a global DNA hypomethylation. ${ }^{[180]}$ In MV4-11 leukaemia cell line, curcumin treatment showed a decrease in DNA methylation with reexpression of epigenetically silenced $P 15$ and a decrease in DNMT1 expression. ${ }^{[181]}$ This suggests an indirect DNA methylation mechanism of curcumin. However, in LNCaP and TRAMP C1 prostate cancer cell lines, a decrease of the DNA methylation inducing the reexpression of Neurog1 and Nrf2 was observed with no effect on the modification of the DNMT1, DNMT3A and DNMT3B expression. ${ }^{[182,183]}$ Curcumin was identified as a very weak inhibitor of DNMT1 and DNMT3A with respectively 34 and $20 \%$ inhibition with $100 \mu \mathrm{M}^{[184]}$ and of M.SssI methyltransferase in a concentration-dependent manner in high micromolar range $(50-100 \mu \mathrm{M}) \cdot{ }^{[183]}$ Surprisingly, using a fluorescence assay Liu et al. reported an inhibition activity of $\mathrm{IC}_{50}=30 \mathrm{nM}$ for curcumin against $M$. SssI methyltransferase. Based on molecular docking, the authors suggested a covalent mode of interaction between curcumin and C1226 of DNMT1. These results are in contradiction with previously reported inhibition activity on DNMT1, as described above. Additionally, the authors observed an in-cell global DNA methylation change with curcumin at concentrations starting from 3 $\mu \mathrm{M}$. Moreover, although curcumin derivative 5 of this paper was calculated to have the same affinity

for DNMT1 by molecular docking, no inhibition was observed in fluorescent enzymatic assay. ${ }^{[185]}$ Globally, similarly to other polyphenolic compounds, curcumin induces DNA methylation inhibition in TSG promoter regions and associated gene re-expression, but, as suggested by the pleiotropic effect of curcumin, this occurs via indirect pathways. The interest of curcumin as therapeutic molecule and its potential PAINs behaviour is still intensively debated. ${ }^{[186,187]}$ 


\section{Natural products altering DNA methylation and identified as DNMTi (Fig. 7)}

\section{Nanaomycin A}

Nanaomycin A is a quinone isolated from Streptomyces sp. culture and first used as antibiotic. ${ }^{[188]}$ In three neuroblastoma cell lines, nanaomycin A induced cell growth inhibition, without global DNA methylation inhibition. ${ }^{[189]}$ In three other human cancer cell lines (colorectal HCT116, lung A549 and leukaemia HL60), increasing concentration of nanomycin A inhibited cell growth and reduced the level of global DNA methylation. In A549 cell line, methylation inhibition at a few CpG sites was measured at the promoter of RASSF1A, with up-regulation of the gene. Biochemical assays indicated that nanaomycin A does not inhibit DNMT1 but inhibits DNMT3B activity with $\mathrm{IC}_{50}=0.5 \mu \mathrm{M} .^{[190]}$ However more studies are needed to assess this suggested selectivity.
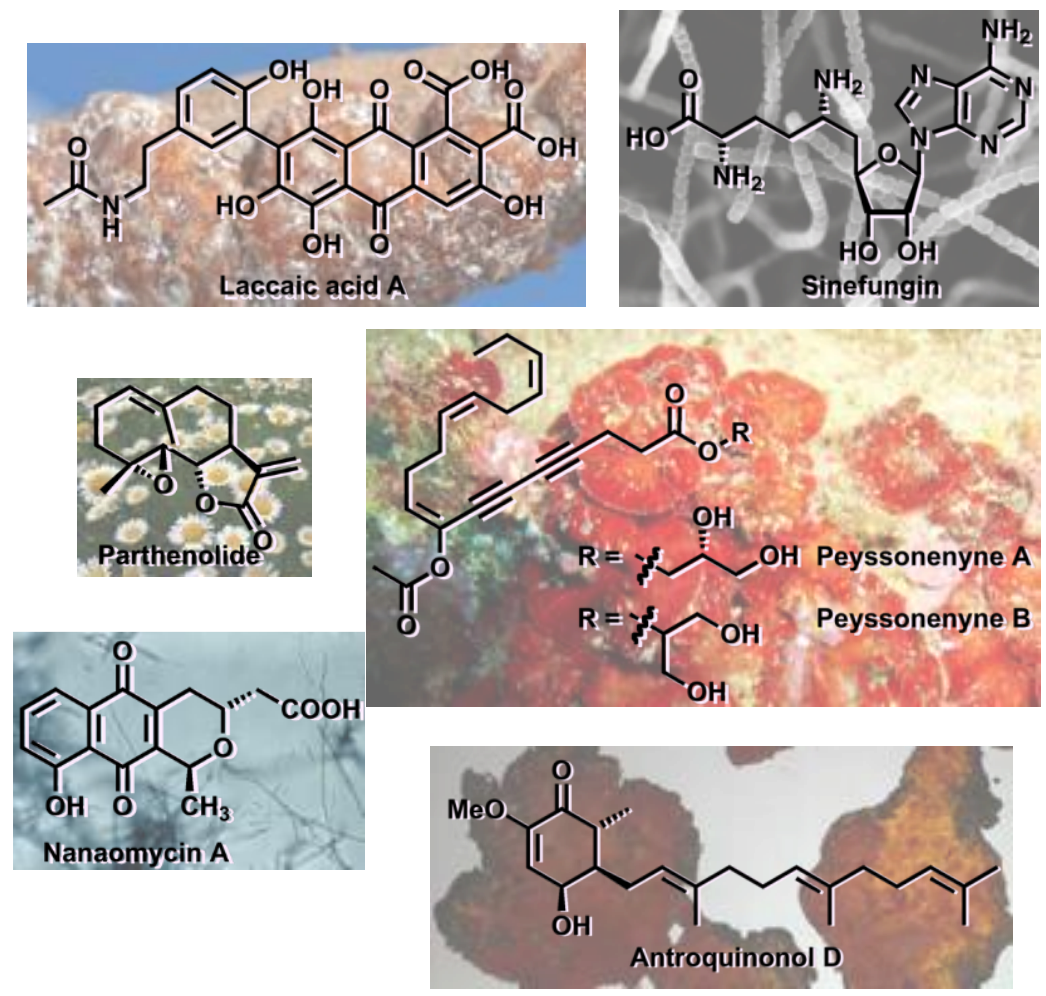
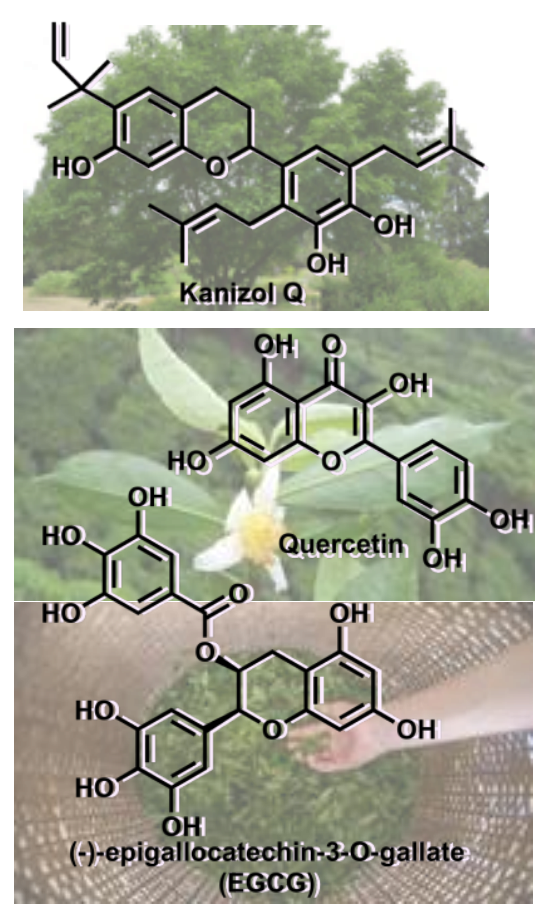

Figure 7: Structure of natural products altering DNA methylation and identified as DNMTi

\section{Laccaic acid}

Laccaic acid extracted from insects, Laccifer lacca Kerr., is a highly substituted anthraquinone used as a natural food dye in Japan that was first identified as toxic against Paramecium caudatum in 1978. ${ }^{[191]}$ This compound was shown to induce the reexpression of $V G F$ and $M A L$ genes over 10 tested genes in 
MCF7 breast cancer cell line and to inhibit an activated, i.e. RFTS-domain lacking, DNMT1 with $K_{i}=$ $310 \mathrm{nM}$ in a DNA-competitive mechanism. Noteworthy, the activated DNMT was reported by the authors to be 640-fold more active than the RFTS domain including enzyme ${ }^{[192]}$ and to date no in-cell DNA methylation inhibition was reported.

\section{Peyssonenynes}

Peyssonenynes $\mathrm{A}$ and $\mathrm{B}$ are two $\omega 3$ fatty acids derivatives isolated from Fijian red marine alga Peyssonnelia caulifera. In a first study, they were reported to have comparable inhibition activity of DNMT1 with $\mathrm{IC}_{50}=16$ and $9 \mu \mathrm{M}$, respectively, using a methyl transfer radioactive enzymatic assay. ${ }^{[193]}$ However more recently, another study reported a 60\% inhibition of DNMT1 with $50 \mu \mathrm{M}$ of peyssonenynes A and B using a similar radioactive assay. This weak inhibition was shown to be still higher than RG108, commonly described as a DNMTi. ${ }^{[194]}$ To date Peyssonenynes A and B have not been studied to evaluate the in-cell DNA methylation inhibition potency.

\section{Parthenolide}

Parthenolide is a sequiterpene lactone identified as NF- $\kappa \mathrm{B}$ transcription factor inhibitor present in the plant Tanacetum parthenium (feverfew) that is used for its anti-inflammatory properties (Lyss 1998, 33508). A global hypomethylation was shown in K562 and MV4-11 leukaemia cell lines and in MV411 xenografted nude mice. The same study reported the hypomethylation of the promoter of the putative TSG HIN-1 associated with the up-regulation of its expression at relatively high dose of parthenolide (i.e. $30 \mu \mathrm{M}){ }^{[195]}$ Parthenolide was also shown to up-regulate the expression of $p 21$ in JB6P+ cells with no effect observed on histone methylation and acetylation. ${ }^{[196]}$ A down-regulation of DNMT1 expression was evidenced in MV4-11 and Kasumi-1 leukaemia cell lines treated with $10 \mu \mathrm{M}$ of partenolide ${ }^{[195]}$ that can lead to an indirect inhibition of the DNA methylation. However, docking experiments suggested a possible covalent direct inhibition of DNMT1 by parthenolide via 1,4conjugated addition between Cys1226 and $\alpha, \beta$-unsaturated carbonyl moiety. ${ }^{[195,197]}$ Fluorescent enzymatic assays showed parthenolide to inhibit M.SssI and DNMT1 with $\mathrm{IC}_{50}=5 \mu \mathrm{M}$ and $3.5 \mu \mathrm{M}$, respectively ${ }^{[195]}$

\section{Kazinol Q}


Kazinol Q was extracted from the root bark of the Formosan plant Broussonetia kazinoki (Ko 1999, 164). In the MDA-MB-231 breast cancer cell line a reexpression of E-cadherin ( $C D H 1)$ gene, silenced through DNA methylation, was observed after $48 \mathrm{~h}$ treatment with $5 \mu \mathrm{M}$ of Kazinol Q whereas no reexpression was observed in this study with EGCG, another natural product identified as DNMTi and described later in this review. Enzymatic assays on DNMT1, lead to the identification of Kazinol Q as the only active inhibitor among 12 structurally diverse compounds isolated from Formosan plants with $\mathrm{IC}_{50}=7 \mu \mathrm{M}$ and compared to EGCG used as positive control $\left(\mathrm{IC}_{50}=3 \mu \mathrm{M}\right)$. Noteworthy the pharmacokinetic properties of Kazinol Q are improved compared to EGCG with increased stability and hydrophobicity. ${ }^{[198]}$

\section{Antroquinonol D}

Antroquinonol D (3-demethoxyl antroquinonol) was isolated from Antrodia camphorate, a mycelium from Taiwan used by aboriginal people as a medicine. Antroquinonol D was shown to inhibit the growth of three breast cancer cell lines (MCF7, T47D and MDA-MB-231) but not of breast epithelial cells (MCF10A and IMR-90). Interestingly, antroquinonol D was reported to inhibit the migration of MDA-MB-231. The treatment of MDA-MB-231 with $15 \mu \mathrm{M}$ of antroquinonol $\mathrm{D}$ for 6 days resulted in a decrease of methylation at CpG sites and an increase of five TSG expression levels (i.e. FANCC, CACNA1A, CHD15, ASB9 and COL4A2). A 75\% inhibition of DNMT1 and a 25\% inhibition of DNMT3B activity were measured using $22 \mu \mathrm{M}$ of antroquinonol D. Contrarily to the inhibition of DNMT3B, the DNMT1 inhibition was shown to be SAM-concentration dependent. With additional molecular docking this enables to hypothesise that it could interact in DNMT1 SAH pocket. ${ }^{[199]}$

\section{Sinefungin}

Sinefungin is a SAM analogue originally isolated from the Streptomyces griseolus bacteria. As expected, this derivative strongly competes with SAM in bacterial $N^{6}$-adenine DNA methyltransferase $\mathrm{M} \bullet$ TaqI. ${ }^{[200]}$ Sinefungin was identified as a weak SAM-competitive DNMT1 inhibitor with $\mathrm{IC}_{50}=80$ $\mu \mathrm{M} \cdot{ }^{[201]}$ As a SAM analogue, this inhibitor can target the full range of SAM-dependent enzymes and as such is not suitable for selective DNMT inhibition. However to date no in cell assays showed evidence of a DNA methylation inhibition of sinefungin in cells. 


\section{Quercetin}

Quercetin is a flavone extracted from green tea that showed a concentration-dependent growth inhibition of colon cancer RKO cell line. After a 5-days treatment, quercetin inhibited, in a concentration-dependent manner, the methylation of the promoter of $P 16^{I N K 4 a}$ gene, ${ }^{[202]}$ key tumour suppressor gene involved in cellular senescence. ${ }^{[203]}$ This was associated with a restored $P 16^{I N K 4 a}$ expression. ${ }^{[202]}$ In prostate cancer cell lines PC3 and DU145, two receptor-negative cell lines, quercetin was shown to decrease global methylation level and induce the reexpression of androgen receptor. ${ }^{[204]}$ The direct inhibition of DNA methyltransferases was investigated on M.SssI methyltransferase and the inhibition level remained very low even at $20 \mu \mathrm{M}^{[160]}$ However as a polyphenol, quercetin is susceptible to be methylated by catechol- $O$-methyltransferase (COMT) and thus deplete the SAM pool. By increasing the concentration of SAH in the medium, quercetin is therefore responsible for the indirect inhibition of SAM-dependent enzyme including DNMTs. The higher inhibition level of quercetin against M.SssI $\left(\mathrm{IC}_{50}=1.6 \mu \mathrm{M}\right)$ in presence of COMT confirmed this hypothesis. ${ }^{[160]}$

\section{(-)-Epigallocatechin-3-gallate}

(-)-Epigallocatechin-3-gallate (EGCG) is the major polyphenol found in green tea (Camellia sinensis). It was first reported to lower promoter methylation and re-induce gene expression of $p 16^{I N K 4 a}, R A R \beta$, $O^{6}$-methylguanine methyltransferase $(M G M T)$ and human MUTL homologue 1 (hMLHI) in esophageal cancer KYSE 510 cell line. ${ }^{[205]}$ Later on, this was also observed on $R A R \beta$ in MCF7 and MDA-MB-231 breast cancer cell lines ${ }^{[160]}$ and GAS1, TIMP4, ICAM1, WISP2 in cisplatin-resistant non-small-cell lung cancer (NSCLC) cells. ${ }^{[206]}$ Several groups with very dissimilar results investigated the inhibition activity of EGCG on purified DNMTs. First, using nuclear extract from KYSE 510 cells, EGCG was identified as the most potent, although very weak, DNMT inhibitor among tested family of dietary polyphenols ${ }^{[205]}$ with about $50 \%$ inhibition at $20 \mu \mathrm{M}$. A competitive mode of inhibition was shown with $K_{i}=6.9 \mu \mathrm{M}$. Another work on purified DNMT1, using radioactive biochemical assay, reported a submicromolar inhibition activity of EGCG with $\mathrm{IC}_{50}=0.47 \mu \mathrm{M} \cdot{ }^{[160]}$ The re-evaluation of EGCG DNMT1 inhibition activity using a similar radioactive assay showed a 
dramatically lower inhibition activity with $\mathrm{IC}_{50}=70 \mu \mathrm{M} \cdot{ }^{[179]}$ This disparity in the inhibition activity questioned the real efficacy of EGCG as DNMTi. Moreover, the direct DNMT inhibition of EGCG in cells was questioned and an indirect mechanism was proposed. As for quercetin, the SAM-dependent COMT was shown to methylate catechol structure of EGCG, which results in a decrease of SAM concentration and an increase in SAH concentration. This can indirectly lower DNMT activity. ${ }^{[207]}$ Nevertheless, Lee et al. studied the EGCG inhibition activity in presence or in absence of COMT and could not see any variation, which tend to show that EGCG inhibition activity is independent of COMT, contrarily to other green tea polyphenol. ${ }^{[160]}$ In addition, EGCG was also identified as HAT inhibitor and as an activator of HDAC 3 recruitment ${ }^{[208]}$ and its instability in culture medium with half-life time of $130 \mathrm{~min}$, due to auto-oxidation and spontaneous degradation, is also to be considered. ${ }^{[209]}$ Therefore, EGCG is a pleiotropic drug with high potential as anticancer prevention, but it mode of action remains to be elucidated, such as most of the flavonoid epigenetic inhibitors. ${ }^{[10]}$

\subsection{Other epigenetics targets}

Besides the most studied epigenetic actors, DNMT and HDAC, several natural products showed activity against other epigenetic targets.

\section{Histone acetyltransferases}

In prostate cancer cell line, genistein re-induced BTG3 expression as a result of decreased DNMT methylation associated with an activation of histone acetyltransferase (HAT). ${ }^{[211]}$ Garcinol, a polyisoprenylated benzophenone derivative extracted from rinds of Garcinia indica fruit was also shown to inhibit PCAF and p300 HAT activity in vitro with $\mathrm{IC}_{50}=5$ and $7 \mu \mathrm{M}$, respectively and repress acetylation in HeLa cell line. ${ }^{[212]}$ Quercetin was also suggested as a HAT inhibitor in mode-K cells. ${ }^{[213]}$ EGCG was shown to inhibit HAT preventing P300-induced P65 acetylation and NF- $\mathrm{BB}$ induction, with no effect on other epigenetic targets such as HDAC, SIRT1 and HMTs. ${ }^{[208]}$

Curcumin was identified as a specific P300/CREB-binding protein (CBP) HAT activity inhibitor and to decrease P300-induced p53 histone acetylation. ${ }^{[214]}$

Histone demethylase 
Quercetin, resveratrol and curcumin were also identified as inhibitors of the histone demethylase LSD1 using an in vitro assay on LSD1 recombinant protein. ${ }^{[215]}$

\section{Histone methyltransferase}

Nahuoic acid A is a polyketide produced by culture of Streptomyces sp. that was reported as the first selective SAM-competitive inhibitor of the histone methyltransferase SETD8 with $\mathrm{IC}_{50}=6.5 \mu \mathrm{M}$ over other HMT including G9a, SETD7, DOT1L, EHMT1 and SUV39H2. ${ }^{[216]}$ Nahuoic acids B-E were also reported as SEDTD8 inhibitor. ${ }^{[217]}$ Curcumin was found to downregulate expression of EZH2, responsible for $\mathrm{H} 3 \mathrm{~K} 27$ methylation in MDA-MB-435. ${ }^{[218]}$ EGCG influences EZH2 expression and H3K27me3 levels but no direct inhibition of EZH2 was demonstrated. ${ }^{[208,219]}$ Sinefungin is reported as micromolar inhibitor of SEDTD2. ${ }^{[220]}$

\section{3/Chemical biology tools to better understand epigenetics in pathological context}

Natural products are an extremely abundant source of new chemical scaffolds for the discovery of epidrugs against cancer. However, although this strategy was quite successful for the identification of HDACi, the inhibition of DNMT by non-nucleoside analogues remains a challenge. The complexity of modulating the deregulated epigenetic mechanism is due to the fact that the epigenetic signature is the result of dynamic pathways, that the epigenetic actors are embedded into dynamic complexes and that these actors cross-talk to establish the epigenetic profile of cells. In order to better understand epigenetic mechanism and to identify innovative pathways to target these mechanisms, the use of appropriate chemical tools associated with chemical biology techniques and proteomic analysis can enable the identification of new targets or novel modes of interaction. ${ }^{[221]}$ In this review, we focused on the chemical tools that were used in living cells and lead to the identification of novel targets or interacting proteins.

In the context of epigenetic mechanisms, the use of chemical probes to scan the epigenetic protein complexes in living cells was first applied in 2007 to identify HADCi interacting proteins, ${ }^{[222]}$ Salisbury et al. synthesised chemical probes containing a SAHA moiety (a FDA-approved HDACi), a photoactivable crosslinker and an alkyne function to be functionalised by affinity group. SAHA was shown to target several class I and II HDACs, but other proteins including RbAp46 and RbAp48 were 
also identified and hypothesised to be part of HDAC complexes. Very interestingly the authors showed that labelling was significantly different in cellular extract and in living cells.

Zhu et al. developed chemical tools based on maleimide-based DNMT inhibitors. ${ }^{[223]}$ The authors added to the maleimide inhibitor moiety an alkyne function to be used as a handle. They first identified this chemical probe as a potent DNMT inhibitor with about $60 \%$ inhibition at $2 \mu \mathrm{M}$ on recombinant DNMT1 and with effect on proliferation with $\mathrm{GI}_{50}=0.3 \mu \mathrm{M}$ on MCF7 breast cancer cell line. Thanks to cellular imaging, they showed that the chemical probe co-localised with the nuclei and with anti-DNMT antibody. Finally, carrying out pull-down on cell lysates with and without competing inhibitor, they were able to identify DNMT1 by western blot. Unfortunately no further proteomic analyses were carried out to identify other potential target of these inhibitors.

The bromodomain targeting compound JQ1 was also modified as chemical probe. First Li et al. synthesised several affinity based probes containing a diazirine crosslinker moiety and a tag (cyclopropene or alkyne). They show a identical binding potency of the probes compared to JQ1 and co-localisation with nuclei by cell imaging. They performed pull-down experiments in HepG2 carcinoma cell line and in competition with JQ1, and identified, together with BRD4 enrichment, a significant enrichment of nine other proteins that could be either other targets of JQ1 or be part of the protein complex of BDR-4. ${ }^{[224]}$ With the aim of identifying chromatin genomic site of JQ1, Anders $e t$ al. synthesised biotinylated derivatives of this bromodomain ligand. They performed a pull-down experiment followed by sequencing analysis in MM1.S multiple myeloma cell line. This Chem-Seq technique showed that the genomic sites bound by biotinylated-JQ1 were similar to the one interacting with BRD2, BRD3 and BRD4 including CCND2.[225]

In another study involving a bromodomain (BRD4)-interacting compound (GW841819X), Pan et al. investigated the influence of a photo-crosslinking group for living cell imaging. The authors reported APEX1 as an off-target of GW841819X and showed the interaction to be responsible of DNMT1 upregulation. ${ }^{[226]}$ This approach has the potential to be be the starting point of a new indirect targeting of DNA methylation. 
A study using chemical probes designed from the histone-lysine $N$-methyltransferase EZH2 inhibitor DzNep was carried out in MCF7 mammalian cells. A large set of proteins was identified including kinases, phosphatases, ATPases, and methyltransferases but without identification of EZH2 or $S$ adenosylhomocysteine hydrolase, SAHH..$^{[227]}$ None of these proteins has been yet validated.

\section{4/ Conclusion - towards new therapeutic targets}

In conclusion, natural products are invaluable resources to explore chemical diversity in order to find new chemical scaffold for therapeutic purposes. Natural products and their derivatives represent about $70 \%$ of the currently used drugs ${ }^{[8]}$ In the field of epi-drugs, natural products are often responsible for pleiotropic effect, which a priori limit their use. The use of chemical tool and affinity-based proteomic experiments involving natural products have not been undertaken yet, although this could be highly valuable to better understand their pathways. Moreover, looking closely, the multi-target effect of natural products can be a real advantage for therapeutic treatments. Multi-target molecules have been recently highly studied in several pathology such as pain management, ${ }^{[228]}$ diabetic cardiomyopathy, ${ }^{[229]}$ cancer, ${ }^{[230,}{ }^{231]}$ and mostly Alzheimer's disease. ${ }^{[232-234]}$ Therefore multi-target therapies using natural products can be an alternative for epigenetic treatment of cancers ${ }^{[235]}$ as long as their mechanisms of action remain well controlled and understood. 


\section{References}

1. Jones PA, Baylin SB. The epigenomics of cancer. Cell. 2007;128(4):683-92.

2. Esteller M. Epigenetics in Cancer. N Engl J Med. 2008;358(11):1148-59.

3. Taylor SM, Jones PA. Mechanism of action of eukaryotic DNA methyltransferase. Use of 5-azacytosinecontaining DNA. J Mol Biol. 1982;162(3):679-92.

4. Creusot F, Acs G, Christman JK. Inhibition of DNA methyltransferase and induction of Friend erythroleukemia cell differentiation by 5-azacytidine and 5-aza-2'-deoxycytidine. J Biol Chem. 1982;257(4):2041-8.

5. Lopez M, Halby L, Arimondo PB. DNA Methyltransferase Inhibitors: Development and Applications. Adv Exp Med Biol. 2016;945:431-73.

6. Wink M. Evolution of secondary metabolites from an ecological and molecular phylogenetic perspective. Phytochemistry. 2003;64(1):3-19.

7. Firn RD, Jones CG. The evolution of secondary metabolism - a unifying model. Mol Microbiol. 2000;37(5):989-94.

8. Newman DJ, Cragg GM. Natural products as sources of new drugs over the 30 years from 1981 to 2010. J Nat Prod. 2012;75(3):311-35.

9. Patridge E, Gareiss P, Kinch MS, Hoyer D. An analysis of FDA-approved drugs: natural products and their derivatives. Drug Discov Today. 2016;21(2):204-7.

10. Roche J, Bertrand P. Inside HDACs with more selective HDAC inhibitors. Eur J Med Chem. 2016;121:451-83.

11. Yao Y-L, Yang W-M. Beyond histone and deacetylase: an overview of cytoplasmic histone deacetylases and their nonhistone substrates. J Biomed Biotechnol. 2011;2011:146493.

12. Micelli C, Rastelli G. Histone deacetylases: structural determinants of inhibitor selectivity. Drug Discov Today. 2015;20(6):718-35.

13. Riggs MG, Whittaker RG, Neumann JR, Ingram VM. n-Butyrate causes histone modification in HeLa and Friend erythroleukaemia cells. Nature. 1977;268(5619):462-4.

14. Boffa LC, Vidali G, Mann RS, Allfrey VG. Suppression of histone deacetylation in vivo and in vitro by sodium butyrate. J Biol Chem. 1978;253(10):3364-6.

15. Mwakwari SC, Patil V, Guerrant W, Oyelere AK. Macrocyclic histone deacetylase inhibitors. Curr Top Med Chem. 2010;10(14):1423-40.

16. Cousens LS, Gallwitz D, Alberts BM. Different accessibilities in chromatin to histone acetylase. J Biol Chem. 1979;254(5):1716-23.

17. Yoshida M, Kijima M, Akita M, Beppu T. Potent and specific inhibition of mammalian histone deacetylase both in vivo and in vitro by trichostatin A. J Biol Chem. 1990;265(28):17174-9.

18. Kijima M, Yoshida M, Sugita K, Horinouchi S, Beppu T. Trapoxin, an antitumor cyclic tetrapeptide, is an irreversible inhibitor of mammalian histone deacetylase. J Biol Chem. 1993;268(30):22429-35.

19. Taunton J, Hassig CA, Schreiber SL. A mammalian histone deacetylase related to the yeast transcriptional regulator Rpd3p. Science. 1996;272(5260):408-11.

20. Taunton J, Collins JL, Schreiber SL. Synthesis of Natural and Modified Trapoxins, Useful Reagents for Exploring Histone Deacetylase Function. J Am Chem Soc. 1996;118(43):10412-22.

21.Tan S, Liu ZP. Natural products as zinc-dependent histone deacetylase inhibitors. ChemMedChem. 2015;10(3):441-50.

22. Negmeldin AT, Padige G, Bieliauskas AV, Pflum MKH. Structural Requirements of HDAC Inhibitors: SAHA Analogues Modified at the C2 Position Display HDAC6/8 Selectivity. ACS Med Chem Lett. 2017;8(3):281-6.

23. Wagner FF, Olson DE, Gale JP, Kaya T, Weiwer M, Aidoud N, et al. Potent and selective inhibition of histone deacetylase 6 (HDAC6) does not require a surface-binding motif. J Med Chem. 2013;56(4):1772-6. 24. Lobera M, Madauss KP, Pohlhaus DT, Wright QG, Trocha M, Schmidt DR, et al. Selective class IIa histone deacetylase inhibition via a nonchelating zinc-binding group. Nat Chem Biol. 2013;9(5):319-25.

25. Melesina J, Praetorius L, Simoben CV, Robaa D, Sippl W. Design of selective histone deacetylase inhibitors: rethinking classical pharmacophore. Future Med Chem. 2018;10(13):1537-40.

26. Ueda H, Nakajima H, Hori Y, Fujita T, Nishimura M, Goto T, et al. FR901228, a novel antitumor bicyclic depsipeptide produced by Chromobacterium violaceum No. 968. I. Taxonomy, fermentation, isolation, physico-chemical and biological properties, and antitumor activity. J Antibiot (Tokyo). 1994;47(3):301-10. 27. Vandermolen KM, McCulloch W, Pearce CJ, Oberlies NH. Romidepsin (Istodax, NSC 630176, FR901228, FK228, depsipeptide): a natural product recently approved for cutaneous T-cell lymphoma. J Antibiot (Tokyo). 2011;64(8):525-31. 
28. Coiffier B, Pro B, Prince HM, Foss F, Sokol L, Greenwood M, et al. Romidepsin for the treatment of relapsed/refractory peripheral T-cell lymphoma: pivotal study update demonstrates durable responses. Journal of hematology \& oncology. 2014;7:11.

29. Narita K, Fukui Y, Sano Y, Yamori T, Ito A, Yoshida M, et al. Total synthesis of bicyclic depsipeptides spiruchostatins $\mathrm{C}$ and $\mathrm{D}$ and investigation of their histone deacetylase inhibitory and antiproliferative activities. Eur J Med Chem. 2013;60:295-304.

30. Narita K, Kikuchi T, Watanabe K, Takizawa T, Oguchi T, Kudo K, et al. Total synthesis of the bicyclic depsipeptide HDAC inhibitors spiruchostatins A and B, 5"-epi-spiruchostatin B, FK228 (FR901228) and preliminary evaluation of their biological activity. Chemistry. 2009;15(42):11174-86.

31. Crabb SJ, Howell M, Rogers H, Ishfaq M, Yurek-George A, Carey K, et al. Characterisation of the in vitro activity of the depsipeptide histone deacetylase inhibitor spiruchostatin A. Biochem Pharmacol. 2008;76(4):463-75.

32. Rehman MU, Jawaid P, Yoshihisa Y, Li P, Zhao QL, Narita K, et al. Spiruchostatin A and B, novel histone deacetylase inhibitors, induce apoptosis through reactive oxygen species-mitochondria pathway in human lymphoma U937 cells. Chem Biol Interact. 2014;221:24-34.

33. Wang C, Henkes LM, Doughty LB, He M, Wang D, Meyer-Almes FJ, et al. Thailandepsins: bacterial products with potent histone deacetylase inhibitory activities and broad-spectrum antiproliferative activities. J Nat Prod. 2011;74(10):2031-8.

34. Biggins JB, Gleber CD, Brady SF. Acyldepsipeptide HDAC inhibitor production induced in Burkholderia thailandensis. Org Lett. 2011;13(6):1536-9.

35. Wang C, Flemming CJ, Cheng YQ. Discovery and activity profiling of thailandepsins A through F, potent histone deacetylase inhibitors, from Burkholderia thailandensis E264. MedChemComm. 2012;3(8):97681.

36. Klausmeyer P, Shipley SM, Zuck KM, McCloud TG. Histone deacetylase inhibitors from Burkholderia thailandensis. J Nat Prod. 2011;74(10):2039-44.

37. Fukui Y, Narita K, Dan S, Yamori T, Ito A, Yoshida M, et al. Total synthesis of burkholdacs A and B and 5,6,20-tri-epi-burkholdac A: HDAC inhibition and antiproliferative activity. Eur J Med Chem. 2014;76:30113.

38. Wilson AJ, Cheng YQ, Khabele D. Thailandepsins are new small molecule class I HDAC inhibitors with potent cytotoxic activity in ovarian cancer cells: a preclinical study of epigenetic ovarian cancer therapy. Journal of ovarian research. 2012;5(1):12.

39. Weinlander E, Somnay Y, Harrison AD, Wang C, Cheng YQ, Jaskula-Sztul R, et al. The novel histone deacetylase inhibitor thailandepsin A inhibits anaplastic thyroid cancer growth. Journal of Surgical Research. 2014;190(1):191-7.

40.Jang S, Janssen A, Aburjania Z, Robers MB, Harrison A, Dammalapati A, et al. Histone deacetylase inhibitor thailandepsin-A activates Notch signaling and suppresses neuroendocrine cancer cell growth in vivo. Oncotarget. 2017;8(41):70828-40.

41.Xiao K, Li YP, Wang C, Ahmad S, Vu M, Kuma K, et al. Disulfide cross-linked micelles of novel HDAC inhibitor thailandepsin A for the treatment of breast cancer. Biomaterials. 2015;67:183-93.

42. Jaskula-Sztul R, Xu W, Chen G, Harrison A, Dammalapati A, Nair R, et al. Thailandepsin A-loaded and octreotide-functionalized unimolecular micelles for targeted neuroendocrine cancer therapy. Biomaterials. 2016;91:1-10.

43. Chen G, Jaskula-Sztul R, Harrison A, Dammalapati A, Xu W, Cheng Y, et al. KE108-conjugated unimolecular micelles loaded with a novel HDAC inhibitor thailandepsin-A for targeted neuroendocrine cancer therapy. Biomaterials. 2016;97:22-33.

44. Hong J, Luesch H. Largazole: from discovery to broad-spectrum therapy. Nat Prod Rep. 2012;29(4):449-56.

45. Taori K, Paul VJ, Luesch H. Structure and activity of largazole, a potent antiproliferative agent from the Floridian marine cyanobacterium Symploca sp. J Am Chem Soc. 2008;130(6):1806-7.

46. Ying Y, Taori K, Kim H, Hong J, Luesch H. Total synthesis and molecular target of largazole, a histone deacetylase inhibitor. J Am Chem Soc. 2008;130(26):8455-9.

47. Benelkebir H, Marie S, Hayden AL, Lyle J, Loadman PM, Crabb SJ, et al. Total synthesis of largazole and analogues: HDAC inhibition, antiproliferative activity and metabolic stability. Bioorg Med Chem. 2011;19(12):3650-8.

48. Souto JA, Vaz E, Lepore I, Poppler AC, Franci G, Alvarez R, et al. Synthesis and biological characterization of the histone deacetylase inhibitor largazole and C7-modified analogues. J Med Chem. 2010;53(12):4654-67. 
49. Guerra-Bubb JM, Bowers AA, Smith WB, Paranal R, Estiu G, Wiest O, et al. Synthesis and HDAC inhibitory activity of isosteric thiazoline-oxazole largazole analogs. Bioorg Med Chem Lett. 2013;23(21):6025-8.

50.Zeng X, Yin B, Hu Z, Liao C, Liu J, Li S, et al. Total synthesis and biological evaluation of largazole and derivatives with promising selectivity for cancers cells. Org Lett. 2010;12(6):1368-71.

51. Liu Y, Salvador LA, Byeon S, Ying Y, Kwan JC, Law BK, et al. Anticolon cancer activity of largazole, a marine-derived tunable histone deacetylase inhibitor. J Pharmacol Exp Ther. 2010;335(2):351-61.

52.Wu LC, Wen ZS, Qiu YT, Chen XQ, Chen HB, Wei MM, et al. Largazole Arrests Cell Cycle at G1 Phase and Triggers Proteasomal Degradation of E2F1 in Lung Cancer Cells. ACS Med Chem Lett. 2013;4(10):921-6.

53. Closse A, Huguenin R. [Isolation and structural clarification of chlamydocin]. Helv Chim Acta. 1974;57(3):533-45.

54. Stahelin H, Trippmacher A. Cytostatic activity of chlamydocin, a rapidly inactivated cyclic tetrapeptide. Eur J Cancer. 1974;10(12):801-8.

55. Walton JD, Earle ED, Stahelin H, Grieder A, Hirota A, Suzuki A. Reciprocal biological activities of the cyclic tetrapeptides chlamydocin and HC-toxin. Experientia. 1985;41(3):348-50.

56. Brosch G, Ransom R, Lechner T, Walton JD, Loidl P. Inhibition of maize histone deacetylases by HC toxin, the host-selective toxin of Cochliobolus carbonum. The Plant cell. 1995;7(11):1941-50.

57. Furumai R, Komatsu Y, Nishino N, Khochbin S, Yoshida M, Horinouchi S. Potent histone deacetylase inhibitors built from trichostatin A and cyclic tetrapeptide antibiotics including trapoxin. Proceedings of the National Academy of Sciences. 2001;98(1):87-92.

58. De Schepper S, Bruwiere H, Verhulst T, Steller U, Andries L, Wouters W, et al. Inhibition of histone deacetylases by chlamydocin induces apoptosis and proteasome-mediated degradation of survivin. J Pharmacol Exp Ther. 2003;304(2):881-8.

59. Du L, Risinger AL, King JB, Powell DR, Cichewicz RH. A potent HDAC inhibitor, 1-alaninechlamydocin, from a Tolypocladium sp. induces G2/M cell cycle arrest and apoptosis in MIA PaCa-2 cells. J Nat Prod. 2014;77(7):1753-7.

60. Itazaki H, Nagashima K, Sugita K, Yoshida H, Kawamura Y, Yasuda Y, et al. Isolation and structural elucidation of new cyclotetrapeptides, trapoxins A and B, having detransformation activities as antitumor agents. J Antibiot (Tokyo). 1990;43(12):1524-32.

61. Porter NJ, Christianson DW. Binding of the Microbial Cyclic Tetrapeptide Trapoxin A to the Class I Histone Deacetylase HDAC8. ACS Chem Biol. 2017;12(9):2281-6.

62. Mori H, Abe F, Yoshimura S, Takase S, Hino M, inventors; Inhibitor of Histone Deacetylase2000.

63. Pringle RB. Amino Acid Composition of the Host-specific Toxin of Helminthosporium carbonum. Plant physiology. 1971;48(6):756-9.

64. Walton JD. HC-toxin. Phytochemistry. 2006;67(14):1406-13.

65. Joung KE, Kim DK, Sheen YY. Antiproliferative effect of trichostatin A and HC-toxin in T47D human breast cancer cells. Arch Pharmacal Res. 2004;27(6):640-5.

66. Min KN, Cho MJ, Kim DK, Sheen YY. Estrogen receptor enhances the antiproliferative effects of trichostatin A and HC-toxin in human breast cancer cells. Arch Pharmacal Res. 2004;27(5):554-61.

67. Deubzer HE, Ehemann V, Westermann F, Heinrich R, Mechtersheimer G, Kulozik AE, et al. Histone deacetylase inhibitor Helminthosporium carbonum (HC)-toxin suppresses the malignant phenotype of neuroblastoma cells. Int J Cancer. 2008;122(8):1891-900.

68. Deubzer HE, Ehemann V, Kulozik AE, Westermann F, Savelyeva L, Kopp-Schneider A, et al. Antineuroblastoma activity of Helminthosporium carbonum (HC)-toxin is superior to that of other differentiating compounds in vitro. Cancer Lett. 2008;264(1):21-8.

69. Zhou W, Chen X, He K, Xiao J, Duan X, Huang R, et al. Histone deacetylase inhibitor screening identifies HC toxin as the most effective in intrahepatic cholangiocarcinoma cells. Oncology reports. 2016;35(5):2535-42.

70. Mori H, Urano Y, Abe F, Furukawa S, Furukawa S, Tsurumi Y, et al. FR235222, a fungal metabolite, is a novel immunosuppressant that inhibits mammalian histone deacetylase (HDAC). I. Taxonomy, fermentation, isolation and biological activities. J Antibiot (Tokyo). 2003;56(2):72-9.

71. Mori H, Abe F, Furukawa S, Furukawa S, Sakai F, Hino M, et al. FR235222, a fungal metabolite, is a novel immunosuppressant that inhibits mammalian histone deacetylase (HDAC) II. Biological activities in animal models. J Antibiot (Tokyo). 2003;56(2):80-6.

72. Matsuoka H, Fujimura T, Mori H, Aramori I, Mutoh S. Mechanism of HDAC inhibitor FR235222mediated IL-2 transcriptional repression in Jurkat cells. Int Immunopharmacol. 2007;7(11):1422-32.

73. Petrella A, D'Acunto CW, Rodriquez M, Festa M, Tosco A, Bruno I, et al. Effects of FR235222, a novel HDAC inhibitor, in proliferation and apoptosis of human leukaemia cell lines: role of annexin A1. Eur J Cancer. 2008;44(5):740-9. 
74. D'Acunto CW, Fontanella B, Rodriquez M, Taddei M, Parente L, Petrella A. Histone deacetylase inhibitor FR235222 sensitizes human prostate adenocarcinoma cells to apoptosis through up-regulation of Annexin A1. Cancer Lett. 2010;295(1):85-91.

75. Gu W, Cueto M, Jensen PR, Fenical W, Silverman RB. Microsporins A and B: new histone deacetylase inhibitors from the marine-derived fungus Microsporum cf. gypseum and the solid-phase synthesis of microsporin A. Tetrahedron. 2007;63(28):6535-41.

76. Darkin-Rattray SJ, Gurnett AM, Myers RW, Dulski PM, Crumley TM, Allocco JJ, et al. Apicidin: a novel antiprotozoal agent that inhibits parasite histone deacetylase. Proceedings of the National Academy of Sciences. 1996;93(23):13143-7.

77. Singh SB, Zink DL, Liesch JM, Dombrowski AW, Darkin-Rattray SJ, Schmatz DM, et al. Structure, histone deacetylase, and antiprotozoal activities of apicidins B and C, congeners of apicidin with proline and valine substitutions. Org Lett. 2001;3(18):2815-8.

78. Singh SB, Zink DL, Liesch JM, Mosley RT, Dombrowski AW, Bills GF, et al. Structure and chemistry of apicidins, a class of novel cyclic tetrapeptides without a terminal alpha-keto epoxide as inhibitors of histone deacetylase with potent antiprotozoal activities. J Org Chem. 2002;67(3):815-25.

79. Jin JM, Lee S, Lee J, Baek SR, Kim JC, Yun SH, et al. Functional characterization and manipulation of the apicidin biosynthetic pathway in Fusarium semitectum. Mol Microbiol. 2010;76(2):456-66.

80.von Bargen KW, Niehaus EM, Bergander K, Brun R, Tudzynski B, Humpf HU. Structure elucidation and antimalarial activity of apicidin F: an apicidin-like compound produced by Fusarium fujikuroi. J Nat Prod. 2013;76(11):2136-40.

81. Khan N, Jeffers M, Kumar S, Hackett C, Boldog F, Khramtsov N, et al. Determination of the class and isoform selectivity of small-molecule histone deacetylase inhibitors. Biochem J. 2008;409(2):581-9.

82. Ahn MY, Chung HY, Choi WS, Lee BM, Yoon S, Kim HS. Anti-tumor effect of apicidin on Ishikawa human endometrial cancer cells both in vitro and in vivo by blocking histone deacetylase 3 and 4 . Int J Oncol. 2010;36(1):125-31.

83. Ahn MY, Kang DO, Na YJ, Yoon S, Choi WS, Kang KW, et al. Histone deacetylase inhibitor, apicidin, inhibits human ovarian cancer cell migration via class II histone deacetylase 4 silencing. Cancer Lett. 2012;325(2):189-99.

84. Ahn MY, Yoon JH. Histone deacetylase 7 silencing induces apoptosis and autophagy in salivary mucoepidermoid carcinoma cells. Journal of Oral Pathology \& Medicine. 2017;46(4):276-83.

85. Han JW, Ahn SH, Park SH, Wang SY, Bae GU, Seo DW, et al. Apicidin, a histone deacetylase inhibitor, inhibits proliferation of tumor cells via induction of p21WAF1/Cip1 and gelsolin. Cancer Res. 2000;60(21):6068-74.

86. Kwon SH, Ahn SH, Kim YK, Bae GU, Yoon JW, Hong S, et al. Apicidin, a histone deacetylase inhibitor, induces apoptosis and Fas/Fas ligand expression in human acute promyelocytic leukemia cells. J Biol Chem. 2002;277(3):2073-80.

87. Cheong JW, Chong SY, Kim JY, Eom JI, Jeung HK, Maeng HY, et al. Induction of apoptosis by apicidin, a histone deacetylase inhibitor, via the activation of mitochondria-dependent caspase cascades in human Bcr-Abl-positive leukemia cells. Clin Cancer Res. 2003;9(13):5018-27.

88. Ueda T, Takai N, Nishida M, Nasu K, Narahara H. Apicidin, a novel histone deacetylase inhibitor, has profound anti-growth activity in human endometrial and ovarian cancer cells. Int J Mol Med. 2007;19(2):301-8.

89. Ahn MY, Lee J, Na YJ, Choi WS, Lee BM, Kang KW, et al. Mechanism of apicidin-induced cell cycle arrest and apoptosis in Ishikawa human endometrial cancer cells. Chemo-Biological Interactions. 2009;179(23):169-77.

90. Ahn MY, Ahn SG, Yoon JH. Apicidin, a histone deaceylase inhibitor, induces both apoptosis and autophagy in human oral squamous carcinoma cells. Oral oncology. 2011;47(11):1032-8.

91. Ahn MY, Ahn JW, Kim HS, Lee J, Yoon JH. Apicidin inhibits cell growth by downregulating IGF-1R in salivary mucoepidermoid carcinoma cells. Oncology reports. 2015;33(4):1899-907.

92. Tsuji N, Kobayashi M, Nagashima K, Wakisaka Y, Koizumi K. A new antifungal antibiotic, trichostatin. J Antibiot (Tokyo). 1976;29(1):1-6.

93. Hanikoglu A, Hanikoglu F, Ozben T. Natural Product Inhibitors of Histone Deacetylases as New Anticancer Agents. Curr Protein Pept Sci. 2018;19(3):333-40.

94. Kramer $\mathrm{OH}$, Gottlicher $\mathrm{M}$, Heinzel $\mathrm{T}$. Histone deacetylase as a therapeutic target. Trends in Endocrinology \& Metabolism. 2001;12(7):294-300.

95. Kang JH, Kim MJ, Chang SY, Sim SS, Kim MS, Jo YH. CCAAT box is required for the induction of human thrombospondin-1 gene by trichostatin A. J Cell Biochem. 2008;104(4):1192-203.

96. Shen S, Kozikowski AP. Why Hydroxamates May Not Be the Best Histone Deacetylase Inhibitors--What Some May Have Forgotten or Would Rather Forget? ChemMedChem. 2016;11(1):15-21. 
97. Kwon HJ, Owa T, Hassig CA, Shimada J, Schreiber SL. Depudecin induces morphological reversion of transformed fibroblasts via the inhibition of histone deacetylase. Proceedings of the National Academy of Sciences. 1998;95(7):3356-61.

98. Arabshahi L, Schmitz FJ. Brominated tyrosine metabolites from an unidentified sponge. J Org Chem. 1987;52(16):3584-6.

99. Schnekenburger M, Dicato M, Diederich M. Epigenetic modulators from "The Big Blue": a treasure to fight against cancer. Cancer Lett. 2014;351(2):182-97.

100. Piña IC, Gautschi JT, Wang G-Y-S, Sanders ML, Schmitz FJ, France D, et al. Psammaplins from the Sponge Pseudoceratina purpurea: Inhibition of Both Histone Deacetylase and DNA Methyltransferase. J Org Chem. 2003;68(10):3866-73.

101. Ahn MY, Jung JH, Na YJ, Kim HS. A natural histone deacetylase inhibitor, Psammaplin A, induces cell cycle arrest and apoptosis in human endometrial cancer cells. Gynecol Oncol. 2008;108(1):27-33.

102. Herman-Antosiewicz A, Singh SV. Signal transduction pathways leading to cell cycle arrest and apoptosis induction in cancer cells by Allium vegetable-derived organosulfur compounds: a review. Mutation Research/Fundamental and Molecular Mechanisms of Mutagenesis. 2004;555(1-2):121-31.

103. Nian H, Delage B, Ho E, Dashwood RH. Modulation of histone deacetylase activity by dietary isothiocyanates and allyl sulfides: studies with sulforaphane and garlic organosulfur compounds. Environ Mol Mutagen. 2009;50(3):213-21.

104. Druesne N, Pagniez A, Mayeur C, Thomas M, Cherbuy C, Duee PH, et al. Repetitive treatments of colon HT-29 cells with diallyl disulfide induce a prolonged hyperacetylation of histone H3 K14. Ann NY Acad Sci. 2004;1030:612-21.

105. Druesne N, Pagniez A, Mayeur C, Thomas M, Cherbuy C, Duee PH, et al. Diallyl disulfide (DADS) increases histone acetylation and p21(waf1/cip1) expression in human colon tumor cell lines. Carcinogenesis. 2004;25(7):1227-36.

106. Druesne-Pecollo N, Pagniez A, Thomas M, Cherbuy C, Duée P-H, Martel P, et al. Diallyl Disulfide Increases CDKN1A Promoter-Associated Histone Acetylation in Human Colon Tumor Cell Lines. J Agric Food Chem. 2006;54(20):7503-7.

107. Altonsy MO, Habib TN, Andrews SC. Diallyl Disulfide-Induced Apoptosis in a Breast-Cancer Cell Line (MCF-7) May Be Caused by Inhibition of Histone Deacetylation. Nutrition and Cancer. 2012;64(8):125160.

108. Zhao J, Huang W-g, He J, Tan H, Liao Q-j, Su Q. Diallyl disulfide suppresses growth of HL-60 cell through increasing histone acetylation and p21WAF1expression in vivo and in vitro. Acta Pharmacol Sin. 2006;27(11):1459-66.

109. Xu S, Simon Cho BH. Allyl mercaptan, a major metabolite of garlic compounds, reduces cellular cholesterol synthesis and its secretion in Hep-G2 cells. J Nutr Biochem. 1999;10(11):654-9.

110. Lea MA, Randolph VM, Patel M. Increased acetylation of histones induced by diallyl disulfide and structurally related molecules. Int J Oncol. 1999;15:347-52.

111. Lea MA, Randolph VM, Lee JE, desBordes C. Induction of histone acetylation in mouse erythroleukemia cells by some organosulfur compounds including allyl isothiocyanate. Int J Cancer. 2001;92(6):784-9.

112. Nian H, Delage B, Pinto JT, Dashwood RH. Allyl mercaptan, a garlic-derived organosulfur compound, inhibits histone deacetylase and enhances Sp3 binding on the P21WAF1 promoter. Carcinogenesis. 2008;29(9):1816-24.

113. Lea MA, Rasheed M, Randolph VM, Khan F, Shareef A, desBordes C. Induction of Histone Acetylation and Inhibition of Growth of Mouse Erythroleukemia Cells by S-Allylmercaptocysteine. Nutrition and Cancer. 2002;43(1):90-102.

114. Son I, Lee S, Yang H, Moon H-I. Bis(4-hydroxybenzyl)sulfide: a Sulfur Compound Inhibitor of Histone Deacetylase Isolated from Root Extract of Pleuropterus ciliinervis. Molecules. 2007;12(4):815-20.

115. Kim E, H. Bisson W, V. Löhr C, E. Williams D, Ho E, H. Dashwood R, et al. Histone and Non-Histone Targets of Dietary Deacetylase Inhibitors. Curr Top Med Chem. 2015;16(7):714-31.

116. Ho E, Clarke JD, Dashwood RH. Dietary Sulforaphane, a Histone Deacetylase Inhibitor for Cancer Prevention. The Journal of nutrition. 2009;139(12):2393-6.

117. Myzak MC, Karplus PA, Chung F-L, Dashwood RH. A Novel Mechanism of Chemoprotection by Sulforaphane. Cancer Res. 2004;64(16):5767-74.

118. Choi SY, Kee HJ, Jin L, Ryu Y, Sun S, Kim GR, et al. Inhibition of class Ila histone deacetylase activity by gallic acid, sulforaphane, TMP269, and panobinostat. Biomed Pharmacother. 2018;101:145-54.

119. Pledgie-Tracy A, Sobolewski MD, Davidson NE. Sulforaphane induces cell type-specific apoptosis in human breast cancer cell lines. Mol Cancer Ther. 2007;6(3):1013-21. 
120. Myzak MC, Tong P, Dashwood WM, Dashwood RH, Ho E. Sulforaphane retards the growth of human PC-3 xenografts and inhibits HDAC activity in human subjects. Exp Biol Med (Maywood). 2007;232(2):227-34.

121. Wang LG, Liu XM, Fang Y, Dai W, Chiao FB, Puccio GM, et al. De-repression of the p21 promoter in prostate cancer cells by an isothiocyanate via inhibition of HDACs and c-Myc. Int J Oncol. 2008;33(2):37580.

122. Zhang R, Loganathan S, Humphreys I, Srivastava SK. Benzyl Isothiocyanate-Induced DNA Damage Causes G2/M Cell Cycle Arrest and Apoptosis in Human Pancreatic Cancer Cells. The Journal of nutrition. 2006;136(11):2728-34.

123. El Amrani M, Lai D, Debbab A, Aly AH, Siems K, Seidel C, et al. Protein Kinase and HDAC Inhibitors from the Endophytic Fungus Epicoccum nigrum. J Nat Prod. 2014;77(1):49-56.

124. Chung IM, Kim MY, Park WH, Moon HI. Histone deacetylase inhibitors from the rhizomes of Zingiber zerumbet. Die Pharmazie. 2008;63(10):774-6.

125. Chen IH, Lu M-C, Du Y-C, Yen M-H, Wu C-C, Chen Y-H, et al. Cytotoxic Triterpenoids from the Stems ofMicrotropis japonica. J Nat Prod. 2009;72(7):1231-6.

126. Kemami Wangun HV, Wood A, Fiorilla C, Reed JK, McCarthy PJ, Wright AE. Gymnochromes E and F, Cytotoxic Phenanthroperylenequinones from a Deep-Water Crinoid,Holopus rangii. J Nat Prod. 2010;73(4):712-5.

127. Oku N, Nagai K, Shindoh N, Terada Y, van Soest RWM, Matsunaga S, et al. Three new cyclostellettamines, which inhibit histone deacetylase, from a marine sponge of the genus Xestospongia. Bioorg Med Chem Lett. 2004;14(10):2617-20.

128. Pandey M, Kaur P, Shukla S, Abbas A, Fu P, Gupta S. Plant flavone apigenin inhibits HDAC and remodels chromatin to induce growth arrest and apoptosis in human prostate cancer cells: In vitro and in vivo study. Molecular carcinogenesis. 2012;51(12):952-62.

129. Godoy LD, Lucas JE, Bender AJ, Romanick SS, Ferguson BS. Targeting the epigenome: Screening bioactive compounds that regulate histone deacetylase activity. Molecular Nutrition \& Food Research. 2017;61(4):1-11.

130. Tseng T-H, Chien M-H, Lin W-L, Wen Y-C, Chow J-M, Chen C-K, et al. Inhibition of MDA-MB-231 breast cancer cell proliferation and tumor growth by apigenin through induction of G2/M arrest and histone $\mathrm{H} 3$ acetylation-mediated p21WAF1/CIP1expression. Environ Toxicol. 2017;32(2):434-44.

131. Berger A, Venturelli S, Kallnischkies M, Böcker A, Busch C, Weiland T, et al. Kaempferol, a new nutrition-derived pan-inhibitor of human histone deacetylases. J Nutr Biochem. 2013;24(6):977-85.

132. Shimoi K, Okada H, Furugori M, Goda T, Takase S, Suzuki M, et al. Intestinal absorption of luteolin and luteolin 7-0- $\beta$-glucoside in rats and humans. FEBS Lett. 1998;438(3):220-4.

133. Morissette M, Litim N, Di Paolo T. Natural Phytoestrogens. Discovery and Development of Neuroprotective Agents from Natural Products: Elsevier; 2018. p. 9-61.

134. Sun L-P, Chen A-L, Hung H-C, Chien Y-H, Huang J-S, Huang C-Y, et al. Chrysin: A Histone Deacetylase 8 Inhibitor with Anticancer Activity and a Suitable Candidate for the Standardization of Chinese Propolis. J Agric Food Chem. 2012;60(47):11748-58.

135. Pal-Bhadra M, Ramaiah MJ, Reddy TL, Krishnan A, Pushpavalli S, Babu KS, et al. Plant HDAC inhibitor chrysin arrest cell growth and induce p21 WAF1 by altering chromatin of STAT response element in A375 cells. BMC Cancer. 2012;12(1):180.

136. Son IH, Chung I-M, Lee SI, Yang HD, Moon H-I. Pomiferin, histone deacetylase inhibitor isolated from the fruits of Maclura pomifera. Bioorg Med Chem Lett. 2007;17(17):4753-5.

137. Jiang Y, Liu J, Chen D, Yan L, Zheng W. Sirtuin Inhibition: Strategies, Inhibitors, and Therapeutic Potential. Trends Pharmacol Sci. 2017;38(5):459-72.

138. Dai H, Sinclair DA, Ellis JL, Steegborn C. Sirtuin activators and inhibitors: Promises, achievements, and challenges. Pharmacol Ther. 2018.

139. Villalba JM, de Cabo R, Alcain FJ. A patent review of sirtuin activators: an update. Expert Opin Ther Pat. 2012;22(4):355-67.

140. Howitz KT, Bitterman KJ, Cohen HY, Lamming DW, Lavu S, Wood JG, et al. Small molecule activators of sirtuins extend Saccharomyces cerevisiae lifespan. Nature. 2003;425(6954):191-6.

141. Zhu X, Liu Q, Wang M, Liang M, Yang X, Xu X, et al. Activation of Sirt1 by resveratrol inhibits TNFalpha induced inflammation in fibroblasts. PLoS One. 2011;6(11):e27081.

142. Kaeberlein M, McDonagh T, Heltweg B, Hixon J, Westman EA, Caldwell SD, et al. Substrate-specific activation of sirtuins by resveratrol. J Biol Chem. 2005;280(17):17038-45.

143. Beher D, Wu J, Cumine S, Kim KW, Lu S-C, Atangan L, et al. Resveratrol is not a direct activator of SIRT1 enzyme activity. Chem Biol Drug Des. 2009;74(6):619-24. 
144. Yang Q, Wang B, Zang W, Wang X, Liu Z, Li W, et al. Resveratrol inhibits the growth of gastric cancer by inducing G1 phase arrest and senescence in a Sirt1-dependent manner. PLoS One. 2013;8(11):e70627. 145. de Boer VC, de Goffau MC, Arts IC, Hollman PC, Keijer J. SIRT1 stimulation by polyphenols is affected by their stability and metabolism. Mechanisms of ageing and development. 2006;127(7):618-27.

146. Anderson RM, Latorre-Esteves M, Neves AR, Lavu S, Medvedik O, Taylor C, et al. Yeast life-span extension by calorie restriction is independent of NAD fluctuation. Science. 2003;302(5653):2124-6.

147. Bitterman KJ, Anderson RM, Cohen HY, Latorre-Esteves M, Sinclair DA. Inhibition of Silencing and Accelerated Aging by Nicotinamide, a Putative Negative Regulator of Yeast Sir2 and Human SIRT1. J Biol Chem. 2002;277(47):45099-107.

148. Lu J, Zhang L, Chen X, Lu Q, Yang Y, Liu J, et al. SIRT1 counteracted the activation of STAT3 and NFkappaB to repress the gastric cancer growth. Int J Clin Exp Med. 2014;7(12):5050-8.

149. Gutierrez M, Andrianasolo EH, Shin WK, Goeger DE, Yokochi A, Schemies J, et al. Structural and synthetic investigations of tanikolide dimer, a SIRT2 selective inhibitor, and tanikolide seco-acid from the Madagascar marine cyanobacterium Lyngbya majuscula. J Org Chem. 2009;74(15):5267-75.

150. Schnekenburger M, Mathieu V, Lefranc F, Jang JY, Masi M, Kijjoa A, et al. The Fungal Metabolite Eurochevalierine, a Sequiterpene Alkaloid, Displays Anti-Cancer Properties through Selective Sirtuin 1/2 Inhibition. Molecules. 2018;23(2):333.

151. Stefanska B, Salame P, Bednarek A, Fabianowska-Majewska K. Comparative effects of retinoic acid, vitamin $\mathrm{D}$ and resveratrol alone and in combination with adenosine analogues on methylation and expression of phosphatase and tensin homologue tumour suppressor gene in breast cancer cells. British Journal of Nutrition. 2012;107(6):781-90.

152. Kala R, Shah HN, Martin SL, Tollefsbol TO. Epigenetic-based combinatorial resveratrol and pterostilbene alters DNA damage response by affecting SIRT1 and DNMT enzyme expression, including SIRT1-dependent gamma-H2AX and telomerase regulation in triple-negative breast cancer. BMC Cancer. 2015;15:672.

153. Mirza S, Sharma G, Parshad R, Gupta SD, Pandya P, Ralhan R. Expression of DNA methyltransferases in breast cancer patients and to analyze the effect of natural compounds on DNA methyltransferases and associated proteins. Journal of breast cancer. 2013;16(1):23-31.

154. Shen Y, Takahashi M, Byun H-M, Link A, Sharma N, Balaguer F, et al. Boswellic acid induces epigenetic alterations by modulating DNA methylation in colorectal cancer cells. Cancer Biology and Therapy. 2012;13(7):542-52.

155. Seo JS, Choi YH, Moon JW, Kim HS, Park SH. Hinokitiol induces DNA demethylation via DNMT1 and UHRF1 inhibition in colon cancer cells. BMC cell biology. 2017;18(1):14.

156. Su ZY, Khor TO, Shu L, Lee JH, Saw CL, Wu TY, et al. Epigenetic reactivation of Nrf2 in murine prostate cancer TRAMP C1 cells by natural phytochemicals Z-ligustilide and Radix angelica sinensis via promoter CpG demethylation. Chem Res Toxicol. 2013;26(3):477-85.

157. Baud MG, Leiser T, Haus P, Samlal S, Wong AC, Wood RJ, et al. Defining the mechanism of action and enzymatic selectivity of psammaplin A against its epigenetic targets. J Med Chem. 2012;55(4):1731-50.

158. Meeran SM, Patel SN, Tollefsbol TO. Sulforaphane causes epigenetic repression of hTERT expression in human breast cancer cell lines. PLoS One. 2010;5(7):e11457.

159. Hsu A, Wong CP, Yu Z, Williams DE, Dashwood RH, Ho E. Promoter de-methylation of cyclin D2 by sulforaphane in prostate cancer cells. Clin Epigenetics. 2011;3:3.

160. Lee WJ, Shim J-Y, Zhu BT. Mechanisms for the Inhibition of DNA Methyltransferases by Tea Catechins and Bioflavonoids. Mol Pharmacol. 2005;68(4):1018-30.

161. Zhu BT, Patel UK, Cai MX, Conney AH. $O$-Methylation of tea polyphenols catalyzed by human placental cytosolic catechol-0-methyltransferase. Drug Metabolism and Disposition. 2000;28(9):1024-30.

162. Cabanes A, Wang M, Olivo S, DeAssis S, Gustafsson JA, Khan G, et al. Prepubertal estradiol and genistein exposures up-regulate BRCA1 mRNA and reduce mammary tumorigenesis. Carcinogenesis. 2004;25(5):741-8.

163. Majid S, Kikuno N, Nelles J, Noonan E, Tanaka Y, Kawamoto K, et al. Genistein induces the p21WAF1/CIP1 and p16INK4a tumor suppressor genes in prostate cancer cells by epigenetic mechanisms involving active chromatin modification. Cancer Res. 2008;68(8):2736-44.

164. Fang MZ, Chen D, Sun Y, Jin Z, Christman JK, Yang CS. Reversal of Hypermethylation and Reactivation of p16INK4a, RAR $\beta$, and MGMT Genes by Genistein and Other Isoflavones from Soy. Clin Cancer Res. 2005;11(19):7033-41.

165. Vardi A, Bosviel R, Rabiau N, Adjakly M, Satih S, Dechelotte P, et al. Soy phytoestrogens modify DNA methylation of GSTP1, RASSF1A, EPH2 and BRCA1 promoter in prostate cancer cells. In Vivo. 2010;24(4):393-400. 
166. King-Batoon A, Leszczynska JM, Klein CB. Modulation of gene methylation by genistein or lycopene in breast cancer cells. Environmental Molecular Mutagenesis. 2008;49(1):36-45.

167. Bosviel R, Dumollard E, Dechelotte P, Bignon Y-J, Bernard-Gallon D. Can soy phytoestrogens decrease DNA methylation in BRCA1 and BRCA2 oncosuppressor genes in breast cancer? Omics : a journal of integrative biology. 2012;16(5):235-44.

168. Xie Q, Bai Q, Zou L-Y, Zhang Q-Y, Zhou Y, Chang H, et al. Genistein inhibits DNA methylation and increases expression of tumor suppressor genes in human breast cancer cells. Genes Chromosom Cancer. 2014;53(5):422-31.

169. Li H, Xu W, Huang Y, Huang X, Xu L, Lv Z. Genistein demethylates the promoter of CHD5 and inhibits neuroblastoma growth in vivo. Int J Mol Med. 2012;30(5):1081-6.

170. Ceccaldi A, Rajavelu A, Champion C, Rampon C, Jurkowska R, Jankevicius G, et al. C5-DNA Methyltransferase Inhibitors: From Screening to Effects on Zebrafish Embryo Development. ChemBioChem. 2011;12(9):1337-45.

171. Basak S, Pookot D, Noonan EJ, Dahiya R. Genistein down-regulates androgen receptor by modulating HDAC6-Hsp90 chaperone function. Mol Cancer Ther. 2008;7(10):3195-202.

172. Akiyama T, Ishida J, Nakagawa S, Ogawara H, Watanabe S, Itoh N, et al. Genistein, a specific inhibitor of tyrosine-specific protein kinases. J Biol Chem. 1987;262(12):5592-5.

173. Okura A, Arakawa H, Oka H, Yoshinari T, Monden Y. Effect of genistein on topoisomerase activity and on the growth of [Val 12]Ha-ras-transformed NIH 3T3 cells. Biochem Biophys Res Commun. 1988;157(1):183-9.

174. Evans BA, Griffiths K, Morton MS. Inhibition of 5 alpha-reductase in genital skin fibroblasts and prostate tissue by dietary lignans and isoflavonoids. J Endocrinol. 1995;147(2):295-302.

175. Li Y, Sarkar FH. Inhibition of nuclear factor kappaB activation in PC3 cells by genistein is mediated via Akt signaling pathway. Clin Cancer Res. 2002;8(7):2369-77.

176. Krishnaswamy K. Traditional Indian spices and their health significance. Asia Pac J Clin Nutr. 2008;17 Suppl 1:265-8.

177. Kunnumakkara AB, Anand P, Aggarwal BB. Curcumin inhibits proliferation, invasion, angiogenesis and metastasis of different cancers through interaction with multiple cell signaling proteins. Cancer Lett. 2008;269(2):199-225.

178. Teiten M-H, Dicato M, Diederich M. Curcumin as a regulator of epigenetic events. Molecular Nutrition \& Food Research. 2013;57(9):1619-29.

179. Medina-Franco JL, López-Vallejo F, Kuck D, Lyko F. Natural products as DNA methyltransferase inhibitors: a computer-aided discovery approach. Mol Divers. 2011;15(2):293-304.

180. Link A, Balaguer F, Shen Y, Lozano JJ, Leung H-C, Boland CR, et al. Curcumin modulates DNA methylation in colorectal cancer cells. PLoS One. 2013;8(2):e57709.

181. Yu J, Peng Y, Wu LC, Xie Z, Deng Y, Hughes T, et al. Curcumin down-regulates DNA methyltransferase 1 and plays an anti-leukemic role in acute myeloid leukemia. PLoS One. 2013;8(2):e55934.

182. Shu L, Khor TO, Lee J, Boyanapalli SS, Huang Y, Wu T-Y, et al. Epigenetic CpG demethylation of the promoter and reactivation of the expression of Neurog1 by curcumin in prostate LNCaP cells. AAPS Journal. 2011;13(4):606-14.

183. Khor TO, Huang Y, Wu T-Y, Shu L, Lee J, Kong A-NT. Pharmacodynamics of curcumin as DNA hypomethylation agent in restoring the expression of Nrf2 via promoter CpGs demethylation. Biochem Pharmacol. 2011;82(9):1073-8.

184. Kuck D, Singh N, Lyko F, Medina-Franco JL. Novel and selective DNA methyltransferase inhibitors: Docking-based virtual screening and experimental evaluation. Bioorganic \& Medicinal Chemistry. 2010;18(2):822-9.

185. Liu Z, Xie Z, Jones W, Pavlovicz RE, Liu S, Yu J, et al. Curcumin is a potent DNA hypomethylation agent. Bioorganic \& medicinal chemistry letters. 2009;19(3):706-9.

186. Nelson KM, Dahlin JL, Bisson J, Graham J, Pauli GF, Walters MA. The Essential Medicinal Chemistry of Curcumin. J Med Chem. 2017;60(5):1620-37.

187. Bahadori F, Demiray M. A Realistic View on "The Essential Medicinal Chemistry of Curcumin". ACS Med Chem Lett. 2017;8(9):893-6.

188. Omura S, Tanaka H, Koyama Y, Oiwa R, Katagiri M. Letter: Nanaomycins A and B, new antibiotics produced by a strain of Streptomyces. J Antibiot (Tokyo). 1974;27(5):363-5.

189. Penter L, Maier B, Frede U, Hackner B, Carell T, Hagemeier C, et al. A rapid screening system evaluates novel inhibitors of DNA methylation and suggests F-box proteins as potential therapeutic targets for high-risk neuroblastoma. Targeted oncology. 2015;10(4):523-33. 
190. Kuck D, Caulfield T, Lyko F, Medina-Franco JL. Nanaomycin A Selectively Inhibits DNMT3B and Reactivates Silenced Tumor Suppressor Genes in Human Cancer Cells. Mol Cancer Ther. 2010;9(11):301523.

191. Sako F, Kobayashi N, Taniguchi N, Takakuwa E. A study on the toxicity of natural food dyes--toxicity and enzyme inhibition in Paramecium caudatum. The Journal of toxicological sciences. 1978;3(2):127-36.

192. Fagan RL, Cryderman DE, Kopelovich L, Wallrath LL, Brenner C. Laccaic Acid A Is a Direct, DNAcompetitive Inhibitor of DNA Methyltransferase 1. J Biol Chem. 2013;288(33):23858-67.

193. McPhail KL, France D, Cornell-Kennon S, Gerwick WH. Peyssonenynes a and B, novel enediyne oxylipins with DNA methyl transferase inhibitory activity from the red marine alga peyssonneliacaulifera. J Nat Prod. 2004;67(6):1010-3.

194. Garcia-Dominguez P, Lepore I, Erb C, Gronemeyer H, Altucci L, Alvarez R, et al. Total synthesis of the proposed structures of the DNA methyl transferase inhibitors peyssonenynes, and structural revision of peyssonenyne B. Org Biomol Chem. 2011;9(20):6979-87.

195. Liu Z, Liu S, Xie Z, Pavlovicz RE, Wu J, Chen P, et al. Modulation of DNA methylation by a sesquiterpene lactone parthenolide. J Pharmacol Exp Ther. 2009;329(2):505-14.

196. Ghantous A, Saikali M, Rau T, Gali-Muhtasib H, Schneider-Stock R, Darwiche N. Inhibition of tumor promotion by parthenolide: epigenetic modulation of p21. Cancer Prev Res. 2012;5(11):1298-309.

197. Yoo J, Medina-Franco JL. Homology modeling, docking and structure-based pharmacophore of inhibitors of DNA methyltransferase. J Comput Aided Mol Des. 2011;25(6):555-67.

198. Weng J-R, Lai IL, Yang H-C, Lin C-N, Bai L-Y. Identification of Kazinol Q, a Natural Product from Formosan Plants, as an Inhibitor of DNA Methyltransferase. Phytother Res. 2014;28(1):49-54.

199. Wang S-C, Lee T-H, Hsu C-H, Chang Y-J, Chang M-S, Wang Y-C, et al. Antroquinonol D, isolated from Antrodia camphorata, with DNA demethylation and anticancer potential. J Agric Food Chem. 2014;62(24):5625-35.

200. Schluckebier G, Kozak M, Bleimling N, Weinhold E, Saenger W. Differential binding of Sadenosylmethionine S-adenosylhomocysteine and Sinefungin to the adenine-specific DNA methyltransferase M.TaqI. J Mol Biol. 1997;265(1):56-67.

201. Gros C, Chauvigné L, Poulet A, Menon Y, Ausseil F, Dufau I, et al. Development of a universal radioactive DNA methyltransferase inhibition test for high-throughput screening and mechanistic studies. Nucleic Acids Res. 2013;41(19):e185-e.

202. Tan S, Wang C, Lu C, Zhao B, Cui Y, Shi X, et al. Quercetin Is Able to Demethylate the p16INK4a Gene Promoter. Chemotherapy. 2009;55:6-10.

203. Hara E, Smith R, Parry D, Tahara H, Stone S, Peters G. Regulation of p16CDKN2 expression and its implications for cell immortalization and senescence. Mol Cell Biol. 1996;16(3):859-67.

204. Sharma V, Kumar L, Mohanty SK, Maikhuri JP, Rajender S, Gupta G. Sensitization of androgen refractory prostate cancer cells to anti-androgens through re-expression of epigenetically repressed androgen receptor - Synergistic action of quercetin and curcumin. Molecular and cellular endocrinology. 2016;431:12-23.

205. Fang MZ, Wang Y, Ai N, Hou Z, Sun Y, Lu H, et al. Tea Polyphenol (-)-Epigallocatechin-3-Gallate Inhibits DNA Methyltransferase and Reactivates Methylation-Silenced Genes in Cancer Cell Lines. Cancer Res. 2003;63(22):7563-70.

206. Zhang Y, Wang X, Han L, Zhou Y, Sun S. Green tea polyphenol EGCG reverse cisplatin resistance of A549/DDP cell line through candidate genes demethylation. Biomed Pharmacother. 2015;69:285-90.

207. Lu H, Meng X, Yang CS. Enzymology of Methylation of Tea Catechins and Inhibition of Catechol-0methyltransferase by (-)-Epigallocatechin Gallate. Drug Metabolism and Disposition. 2003;31(5):572-9.

208. Choi K-C, Jung MG, Lee Y-H, Yoon JC, Kwon SH, Kang H-B, et al. Epigallocatechin-3-gallate, a histone acetyltransferase inhibitor, inhibits EBV-induced B lymphocyte transformation via suppression of RelA acetylation. Cancer Res. 2009;69(2):583-92.

209. Naasani I, Oh-Hashi F, Oh-Hara T, Feng WY, Johnston J, Chan K, et al. Blocking telomerase by dietary polyphenols is a major mechanism for limiting the growth of human cancer cells in vitro and in vivo. Cancer Res. 2003;63(4):824-30.

210. Busch C, Burkard M, Leischner C, Lauer UM, Frank J, Venturelli S. Epigenetic activities of flavonoids in the prevention and treatment of cancer. Clin Epigenetics. 2015;7(1):64.

211. Majid S, Dar AA, Shahryari V, Hirata H, Ahmad A, Saini S, et al. Genistein reverses hypermethylation and induces active histone modifications in tumor suppressor gene B-Cell translocation gene 3 in prostate cancer. Cancer. 2010;116(1):66-76.

212. Balasubramanyam K, Altaf M, Varier RA, Swaminathan V, Ravindran A, Sadhale PP, et al. Polyisoprenylated Benzophenone, Garcinol, a Natural Histone Acetyltransferase Inhibitor, Represses Chromatin Transcription and Alters Global Gene Expression. J Biol Chem. 2004;279(32):33716-26. 
213. Ruiz PA, Braune A, Holzlwimmer G, Quintanilla-Fend L, Haller D. Quercetin inhibits TNF-induced NFkappaB transcription factor recruitment to proinflammatory gene promoters in murine intestinal epithelial cells. Journal of Nutrition. 2007;137(5):1208-15.

214. Balasubramanyam K, Varier RA, Altaf M, Swaminathan V, Siddappa NB, Ranga U, et al. Curcumin, a Novel p300/CREB-binding Protein-specific Inhibitor of Acetyltransferase, Represses the Acetylation of Histone/Nonhistone Proteins and Histone Acetyltransferase-dependent Chromatin Transcription. J Biol Chem. 2004;279(49):51163-71.

215. Abdulla A, Zhao X, Yang F. Natural Polyphenols Inhibit Lysine-Specific Demethylase-1 in vitro. Journal of biochemical and pharmacological research. 2013;1(1):56-63.

216. Williams DE, Dalisay DS, Li F, Amphlett J, Maneerat W, Chavez MA, et al. Nahuoic acid A produced by a Streptomyces sp. isolated from a marine sediment is a selective SAM-competitive inhibitor of the histone methyltransferase SETD8. Org Lett. 2013;15(2):414-7.

217. Williams DE, Izard F, Arnould S, Dalisay DS, Tantapakul C, Maneerat W, et al. Structures of Nahuoic Acids B-E Produced in Culture by a Streptomyces sp. Isolated from a Marine Sediment and Evidence for the Inhibition of the Histone Methyl Transferase SETD8 in Human Cancer Cells by Nahuoic Acid A. J Org Chem. 2016;81(4):1324-32.

218. Hua WF, Fu YS, Liao YJ, Xia WJ, Chen YC, Zeng YX, et al. Curcumin induces down-regulation of EZH2 expression through the MAPK pathway in MDA-MB-435 human breast cancer cells. Eur J Pharmacol. 2010;637(1-3):16-21.

219. Deb G, Thakur VS, Limaye AM, Gupta S. Epigenetic induction of tissue inhibitor of matrix metalloproteinase-3 by green tea polyphenols in breast cancer cells. Molecular carcinogenesis. 2015;54(6):485-99.

220. Zheng W, Ibáñez G, Wu H, Blum G, Zeng H, Dong A, et al. Sinefungin Derivatives as Inhibitors and Structure Probes of Protein Lysine Methyltransferase SETD2. J Am Chem Soc. 2012;134(43):18004-14.

221. Weigt D, Hopf C, Medard G. Studying epigenetic complexes and their inhibitors with the proteomics toolbox. Clin Epigenetics. 2016;8:76.

222. Salisbury CM, Cravatt BF. Activity-based probes for proteomic profiling of histone deacetylase complexes. Proc Natl Acad Sci U S A. 2007;104(4):1171-6.

223. Zhu B, Ge J, Yao SQ. Developing new chemical tools for DNA methyltransferase 1 (DNMT 1): a smallmolecule activity-based probe and novel tetrazole-containing inhibitors. Bioorganic \& Medicinal Chemistry. 2015;23(12):2917-27.

224. Li Z, Wang D, Li L, Pan S, Na Z, Tan CY, et al. "Minimalist" cyclopropene-containing photo-crosslinkers suitable for live-cell imaging and affinity-based protein labeling. J Am Chem Soc. 2014;136(28):9990-8.

225. Anders L, Guenther MG, Qi J, Fan ZP, Marineau JJ, Rahl PB, et al. Genome-wide localization of small molecules. Nat Biotech. 2014;32(1):92-6.

226. Pan S, Jang S-Y, Wang D, Liew SS, Li Z, Lee J-S, et al. A Suite of "Minimalist" Photo-Crosslinkers for Live-Cell Imaging and Chemical Proteomics: Case Study with BRD4 Inhibitors. Angewandte Chemie International Edition in English. 2017;56(39):11816-21.

227. Tam EKW, Li Z, Goh YL, Cheng X, Wong SY, Santhanakrishnan S, et al. Cell-based proteome profiling using an affinity-based probe (AfBP) derived from 3-deazaneplanocin A (DzNep). Chem Asian J. 2013;8(8):1818-28.

228. Turnaturi R, Arico G, Ronsisvalle G, Pasquinucci L, Parenti C. Multitarget Opioid/Non-opioid Ligands: A Potential Approach in Pain Management. Curr Med Chem. 2016;23(40):4506-28.

229. Karuppagounder V, Arumugam S, Giridharan VV, Sreedhar R, Bose RJ, Vanama J, et al. Tiny molecule, big power: Multi-target approach for curcumin in diabetic cardiomyopathy. Nutrition. 2017;34:47-54.

230. Badal SAM, Aiken WD, Chin SN. Molecular Targets and Angiogenesis in Renal Cell Carcinoma, A Multitarget Approach: Mini Review. Current drug targets. 2017;18(10):1204-13.

231. Musso L, Dallavalle S, Zunino F. Perspectives in the development of hybrid bifunctional antitumour agents. Biochem Pharmacol. 2015;96(4):297-305.

232. Rosini M, Simoni E, Caporaso R, Minarini A. Multitarget strategies in Alzheimer's disease: benefits and challenges on the road to therapeutics. Future Med Chem. 2016;8(6):697-711.

233. Santos MA, Chand K, Chaves S. Recent progress in repositioning Alzheimer's disease drugs based on a multitarget strategy. Future Med Chem. 2016;8(17):2113-42.

234. Prati F, Bottegoni G, Bolognesi ML, Cavalli A. BACE-1 Inhibitors: From Recent Single-Target Molecules to Multitarget Compounds for Alzheimer's Disease. J Med Chem. 2018;61(3):619-37.

235. de Lera AR, Ganesan A. Epigenetic polypharmacology: from combination therapy to multitargeted drugs. Clin Epigenetics. 2016;8:105. 